\title{
Contrasting composition of terrigenous organic matter in the dissolved, particulate and sedimentary organic carbon pools on the outer East Siberian Arctic Shelf
}

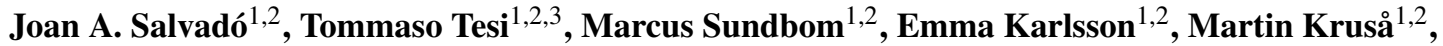 \\ Igor P. Semiletov ${ }^{4,5,6}$, Elena Panova ${ }^{4}$, and Örjan Gustafsson ${ }^{1,2}$ \\ ${ }^{1}$ Department of Environmental Science and Analytical Chemistry (ACES), Stockholm University, 10691 \\ Stockholm, Sweden \\ ${ }^{2}$ Bolin Centre for Climate Research, Stockholm University, 10691 Stockholm, Sweden \\ ${ }^{3}$ CNR-National Research Council of Italy, ISMAR-Marine Sciences Institute in Bologna, Via P. Gobetti 101, \\ 40129 Bologna, Italy \\ ${ }^{4}$ Tomsk National Research Politechnical University, Tomsk, Russia \\ ${ }^{5}$ Pacific Oceanological Institute, Russian Academy of Sciences Far Eastern Branch, Vladivostok 690041, Russia \\ ${ }^{6}$ International Arctic Research Center, University Alaska Fairbanks, Fairbanks, AK 99775, USA
}

Correspondence to: Örjan Gustafsson (orjan.gustafsson@aces.su.se)

Received: 16 June 2016 - Published in Biogeosciences Discuss.: 28 June 2016

Revised: 9 October 2016 - Accepted: 15 October 2016 - Published: 14 November 2016

\begin{abstract}
Fluvial discharge and coastal erosion of the permafrost-dominated East Siberian Arctic delivers large quantities of terrigenous organic carbon (Terr-OC) to marine waters. The composition and fate of the remobilized TerrOC needs to be better constrained as it impacts the potential for a climate-carbon feedback. In the present study, the bulk isotope $\left(\delta^{13} \mathrm{C}\right.$ and $\Delta^{14} \mathrm{C}$ ) and macromolecular (ligninderived phenols) composition of the cross-shelf exported organic carbon (OC) in different marine pools is evaluated. For this purpose, as part of the SWERUS-C3 expedition (JulySeptember 2014), sediment organic carbon (SOC) as well as water column (from surface and near-bottom seawater) dissolved organic carbon (DOC) and particulate organic carbon (POC) samples were collected along the outer shelves of the Kara Sea, Laptev Sea and East Siberian Sea. The results show that the Lena River and the DOC may have a preferential role in the transport of Terr-OC to the outer shelf. DOC concentrations (740-3600 $\left.\mathrm{g} \mathrm{L}^{-1}\right)$ were 1 order of magnitude higher than POC $\left(20-360 \mu \mathrm{g} \mathrm{L}^{-1}\right)$, with higher concentrations towards the Lena River plume. The $\delta^{13} \mathrm{C}$ signatures in the three carbon pools varied from $-23.9 \pm 1.9 \%$ o in the SOC, $-26.1 \pm 1.2 \%$ in the DOC and $-27.1 \pm 1.9 \%$ o in the POC. The $\Delta^{14} \mathrm{C}$ values ranged between $-395 \pm 83$
\end{abstract}

(SOC), $-226 \pm 92$ (DOC) and $-113 \pm 122 \%$ (POC). These stable and radiocarbon isotopes were also different between the Laptev Sea and the East Siberian Sea. Both DOC and POC showed a depleted and younger trend off the Lena River plume. Further, the Pacific inflow and the sea-ice coverage, which works as a barrier preventing the input of "young" DOC and POC, seem to have a strong influence in these carbon pools, presenting older and more enriched $\delta^{13} \mathrm{C}$ signatures under the sea-ice extent. Lignin phenols exhibited higher OC-normalized concentrations in the SOC $(0.10$ $\left.2.34 \mathrm{mg} \mathrm{g}^{-1} \mathrm{OC}\right)$ and DOC $\left(0.08-2.40 \mathrm{mg} \mathrm{g}^{-1} \mathrm{OC}\right)$ than in the POC (0.03-1.14 $\left.\mathrm{mg} \mathrm{g}^{-1} \mathrm{OC}\right)$. The good relationship between lignin and $\Delta^{14} \mathrm{C}$ signatures in the DOC suggests that a significant fraction of the outer-shelf DOC comes from "young" Terr-OC. By contrast, the slightly negative correlation between lignin phenols and $\Delta^{14} \mathrm{C}$ signatures in POC, with higher lignin concentrations in older POC from nearbottom waters, may reflect the off-shelf transport of $\mathrm{OC}$ from remobilized permafrost in the nepheloid layer. Syringyl / vanillyl and cinnamyl / vannillyl phenol ratios presented distinct clustering between DOC, POC and SOC, implying that those pools may be carrying different Terr-OC of partially different origin. Moreover, 3,5-dihydroxybenzoic 
acid to vanillyl phenol ratios and $p$-coumaric acid to ferulic acid ratios, used as a diagenetic indicators, enhanced in POC and SOC, suggesting more degradation within these pools. Overall, the key contrast between enhanced lignin yields both in the youngest DOC and the oldest POC samples reflects a significant decoupling of terrestrial OC sources and pathways.

\section{Introduction}

Studies of terrestrial organic carbon (Terr-OC) in the Arctic Ocean are receiving increasing interest due to concerns about the consequences on the carbon cycle by amplified climate change. The Eurasian Arctic Shelf is predicted to experience the highest increase in temperature on Earth, and its warming is even faster than predicted (Arndt et al., 2015; Zwiers, 2002). The sources and the inputs of Terr-OC are likely to vary in the northern shelf margin due to the changing climate. It has been suggested that these changes may translocate increasing amounts of Terr-OC to the coastal ocean (Vonk and Gustafsson, 2013). The Arctic tundra and taiga drainage basins represent roughly $50 \%$ of the global soil organic matter, much within shallow permafrost (Gorham, 1991; Tarnocai et al., 2009), and 10-20\% of the global vegetation carbon with about $73 \%$ in Eurasia (McGuire et al., 2009, 2010). Fluvial and erosional processes are expected to increase, as well as biomass cover, resulting in higher input fluxes and changing composition of Terr-OC to the continental shelf (Lantuit et al., 2013; Peterson et al., 2002; Sanchez-Garcia et al., 2014; Serreze et al., 2002). In addition, those mechanisms would enhance the remobilization of permafrost carbon, potentially constituting a climate-carbon positive feedback, in terms of $\mathrm{CO}_{2}$ outgassing from degradation of thawing permafrost. Thus, it is essential to understand the sources, dynamical fate and composition of exported Terr-OC in order to assess its impact within the carbon cycle.

The fate of Terr-OC in the dissolved organic carbon (DOC), particulate organic carbon (POC) and sedimentary organic carbon (SOC) compartments of the marine system is still a matter of debate. Some studies have indicated a conservative behavior of DOC in the Arctic Ocean with a small influence on the ocean-atmosphere exchange of $\mathrm{CO}_{2}$ (Amon and Meon, 2004; Dittmar and Kattner, 2003a; Köhler et al., 2003; McGuire et al., 2009), little or no degradation in microbial incubations (Amon and Meon, 2004), and high concentrations of lignin in the DOC pool (Amon and Benner, 2003; Amon et al., 2012; Lobbes et al., 2000). By contrast, others suggest that DOC is highly degraded by photochemical oxidation or microbial respiration in the water column or surface sediments (Alling et al., 2010; Benner and Kaiser, 2011; Hernes and Benner, 2003; van Dongen et al., 2008b). Investigations of the particulate compartment indicate that POC

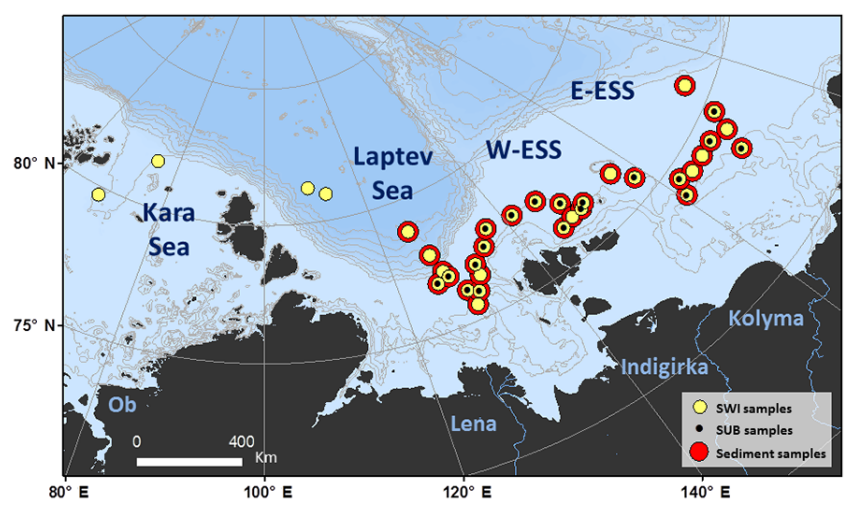

Figure 1. Map of the Eurasian Arctic Shelf including the Kara, Laptev and East Siberian seas (E-ESS, eastern East Siberian Sea; W-ESS, western East Siberian Sea). SWI samples: seawater intake samples (surface water samples at $8 \mathrm{~m}$ depth); SUB samples: samples obtained by submersible pump (near-bottom water samples, $5 \mathrm{~m}$ above bottom).

degrades much faster than DOC, and just a small fraction is transported off-shelf within the POC pool (Eglinton and Repeta, 2006; Sanchez-Garcia et al., 2011; van Dongen et al., 2008b). In addition, other processes on the wide and shallow Arctic shelves such as hydrodynamic sorting, deposition, resuspension and uptake by primary production may contribute to the dilution/dispersal of Terr-OC along the water and sediment dispersal system (Stein and Macdonald, 2004; Tesi et al., 2014, 2016). It seems that different pools of Terr-OC have different behavior and fate during remobilization and transport. DOC and POC pools have much younger ${ }^{14} \mathrm{C}$ ages than the deposited sedimentary OC (Guo et al., 2007; Karlsson et al., 2011, 2016). Compound-specific radiocarbon analyses of lipid molecules and lignin phenols of surface sediments and POC from major river mouths in the Arctic revealed marked age offsets between different Terr-OC pools (Feng et al., 2013; Vonk et al., 2010), but POC in the Eurasian rivers is not well characterized. Further, we still have a very limited understanding of the composition and cycling of Terr-OC in the Arctic Ocean.

The East Siberian Arctic Shelf (ESAS) is a particularly relevant region for investigating the distribution and fate of Terr-OC in the DOC, POC and SOC pools. The ESAS is the world's largest continental shelf and its adjacent basin is located in a region of continuous and discontinuous permafrost. The extensive ESAS is quite shallow $(\sim 50 \mathrm{~m}$ average depth) and receives massive amounts of Terr-OC $\left(22 \pm 8 \mathrm{Tg} \mathrm{OC} \mathrm{yr}^{-1}\right.$; Vonk et al., 2012). In the west, the Lena River and coastal erosion are the main inputs of OC (Laptev Sea and western East Siberian Sea (W-ESS); Charkin et al., 2011; Salvadó et al., 2015; Semiletov et al., 2011; Tesi et al., 2014; Vonk et al., 2012). Alternatively, in the eastern East Siberian Sea (E-ESS, from $\sim 160^{\circ} \mathrm{E}$ to eastwards) marine phytoplankton represents an important source of OC due to 
the influence of nutrient-rich Pacific inflow waters (Semiletov et al., 2005; Stein and Macdonald, 2004). Many investigations in the Arctic focused on characterizing the composition and fate of riverine OC (Amon et al., 2012; Benner et al., 2005; Elmquist et al., 2008; Goni et al., 2000; Lobbes et al., 2000; van Dongen et al., 2008a; Winterfeld et al., 2015), sedimentary OC in the ESAS (Bröder et al., 2016; Karlsson et al., 2015; Salvadó et al., 2015; Tesi et al., 2014), and DOC and POC in the water column of the Eurasian Arctic Shelf (Alling et al., 2010; Sanchez-Garcia et al., 2011). This is, however, the first study that characterizes collectively the DOC, POC and SOC pools along the outer shelf, seeking to test the hypothesis that carbon pools may carry different types of OC with different propensity toward off-shelf transport and degradation. The present study uses carbon isotopes and macromolecular biomarkers to provide an extensive view of the composition and distribution of Terr-OC along the outer ESAS, with the objective to evaluate the sources, degradation and off-shelf transport of the DOC, POC and SOC pools.

\section{Materials and methods}

\subsection{Study area}

The ESAS is the widest, shallowest and, by area, largest continental shelf in the World Ocean. It comprises $40 \%$ of the Arctic shelf and $20 \%$ of the Arctic Ocean (Stein and Macdonald, 2004). This study focuses on the outer shelf of ESAS seas (Laptev Sea and East Siberian Sea) and the Kara Sea (Fig. 1). The Kara Sea has an area of $880 \times 10^{3} \mathrm{~km}^{2}$ and a mean depth of $110 \mathrm{~m}$. It receives a large amount of fresh water, mainly from the Ob' River. The Laptev Sea, between $\sim 110$ and $140^{\circ} \mathrm{E}$, covers almost $500 \times 10^{3} \mathrm{~km}^{2}$ and has an average water depth of $50 \mathrm{~m}$. This sea receives large amounts of freshwater $\left(\sim 745 \mathrm{~km}^{3} \mathrm{yr}^{-1}\right)$, mainly transported by the Lena River $\left(566 \mathrm{~km}^{3} \mathrm{yr}^{-1}\right.$; Cooper et al., 2008; Semiletov et al., 2000), but most of the Terr-OC that enters the Laptev Sea is coming from coastal erosion of late Pleistocene ice complex deposits ( $53 \pm 5 \%$; Semiletov et al., 2011; Vonk et al., 2012). The East Siberian Sea has an average water depth of $58 \mathrm{~m}$, and is the largest and most icebound shelf sea of the Arctic Ocean (Stein and Macdonald, 2004). It extends from 140 to $180^{\circ} \mathrm{E}$ covering an area of $987 \times 10^{3} \mathrm{~km}^{2}$, and receives freshwater inputs from the Indigirka and Kolyma rivers. This sea exhibits two physical and biogeochemical regimes: (i) the eastern East Siberian Sea (E$\mathrm{ESS}$, from $\sim 160$ to $\sim 180^{\circ} \mathrm{E}$ ), which is influenced by the $\mathrm{Pa}-$ cific inflow waters, and where primary production represents an important source of OC (Semiletov et al., 2005; Stein and Macdonald, 2004), and (ii) the western East Siberian Sea (WESS) between $\sim 140$ and $\sim 160^{\circ} \mathrm{E}$, where river runoff and coastal erosion of thawing permafrost supply the major part of $\mathrm{OC}$, but there is also a relatively high marine productivity, particularly in certain polynya regions.

\subsection{Sampling}

A comprehensive set of samples was obtained during JulyAugust 2014 as part of the international Swedish-RussianUS investigation of the Carbon-Climate-Cryospshere Interactions in the East Siberian Arctic Ocean (SWERUS-C3) expedition onboard I/B Oden. The first of two SWERUS-C3 2014 legs was an extensive 45-day campaign of complex geophysical and hydrogeochemical sampling including atsea analysis. The sample collection for this study consisted of four types of samples along the outer ESAS (Fig. 1): (i) POC from high volume filtration on $293 \mathrm{~mm}$ glass fibre filter (GF/F; Whatman Inc.) with a nominal $0.7 \mu \mathrm{m}$ cut-off, (ii) POC from $47 \mathrm{~mm}$ Teflon filters ( $1 \mu \mathrm{m}$ cut-off), (iii) DOC isolated with solid phase extraction (SPE) cartridges, (iv) surface sediment samples collected with a multicorer.

Surface and near-bottom waters ( $5 \mathrm{~m}$ above bottom) were sampled and filtered through high volume $293 \mathrm{~mm}$ GF/F filters (pre-combusted for $5 \mathrm{~h}$ at $500^{\circ} \mathrm{C}$ ). Samples were filtered either directly from the seawater intake (SWI) or by pumping water from $1000 \mathrm{~L}$ tanks filled from the SWI or from a submersible pump. The systems were connected to an electronic flow meter, in the flow path below the filter, and a pressure meter situated directly above the GF/F filter holder. We maintained the flow to about $8.5 \mathrm{~L} \mathrm{~min}^{-1}$, and stopped filtering before the backpressure reached 1 bar to avoid cell lysing. After sampling of the particulate fraction, the GF/F filters were folded, put in a pre-combusted aluminium foil and stored at $-20^{\circ} \mathrm{C}$. Since GF/F filters are not compatible with the alkaline hydrolysis of the $\mathrm{CuO}$ oxidation protocol to analyze lignin-derived phenols, POC samples were also obtained on $47 \mathrm{~mm}$ Teflon filters in order to analyze lignin-derived phenols in POC. We placed the Teflon filters in the filtration unit and applied a positive pressure flow with a peristaltic pump at a flow rate of $25 \mathrm{~mL} \mathrm{~min}^{-1}$. POC samples in Teflon filters were folded in two, placed in petri dishes and stored frozen $\left(-20^{\circ} \mathrm{C}\right)$ until laboratory analysis.

The dissolved fraction of organic matter was isolated by high-volume SPE cartridges containing $10 \mathrm{~g}$ of sorption material composed of octadecyl carbon moieties $\left(\mathrm{C}_{18}\right)$ chemically bonded to a silica support $\left(\mathrm{C}_{18}\right.$-SPE Mega-Bond Elut; Agilent; Louchouarn et al., 2000). Cartridges were preconditioned with 5 resin volumes of methanol followed by 5 resin volumes of acidified $(\mathrm{pH} 2)$ Milli-Q Plus UV water. The water samples, previously filtered with $\mathrm{GF} / \mathrm{F}$, were acidified to $\mathrm{pH} 2$ using reagent-grade concentrated $\mathrm{HCl}$ and pumped through the SPE cartridge with a peristaltic pump and silicone tubing. By this method, the water $(\sim 30 \mathrm{~L})$ was delivered directly into the headspace of the SPE cartridge and forced by pressure through the sorbent at a flow rate of $100 \mathrm{~mL} \mathrm{~min}^{-1}$. Thereafter, we rinsed each SPE cartridge with $1 \mathrm{~L}$ of acidified ( $\mathrm{pH}$ 2) Milli-Q Plus UV water to remove 
residual salts. Sample cartridges were packed in aluminum foil and stored at $4{ }^{\circ} \mathrm{C}$ until further processing.

Sediment cores were collected at water depths of 40 to $3120 \mathrm{~m}$ with an 8-tube multicorer (Oktopus $\mathrm{GmbH}$, Germany), which was developed to collect samples of the seabed with an undisturbed sediment-water interface. The liners were made of polycarbonate and were $60 \mathrm{~cm}$ long with a $10 \mathrm{~cm}$ diameter. The multicorer was deployed with full weight (head weight about $500 \mathrm{~kg}$ ) at a speed of $0.5 \mathrm{~m} \mathrm{~s}^{-1}$ near the seabed. To increase recoveries, the multicorer was left for $1 \mathrm{~min}$ on the seafloor. The cores were sectioned on low resolution $(1 \mathrm{~cm}$ intervals; shelf stations $<200 \mathrm{~m}$ water depth) or on high resolution $(0.5 \mathrm{~cm}$ intervals; slope and rise stations $>200 \mathrm{~m}$ water depth), and sediment samples were transferred into plastic bags and stored in the freezer $\left(-20^{\circ} \mathrm{C}\right)$. This study focuses on surface sediments $(0-1 \mathrm{~cm})$.

\subsection{Bulk elemental and isotope analysis}

The analyses of organic carbon content, $\delta^{13} \mathrm{C}$ and $\Delta^{14} \mathrm{C}$ in the DOC, POC and SOC pools have been described earlier (Karlsson et al., 2011; Louchouarn et al., 2000). Briefly, DOC was determined onboard after GF/F filtration by hightemperature catalytic oxidation (Shimadzu TOC-L $\mathrm{L}_{\mathrm{CPH}}$ ). In the laboratory, SPE cartridges were eluted with $50 \mathrm{~mL}$ of methanol. Then, we subsampled $0.5-1 \mathrm{~mL}$ of the eluent, depending on DOC concentrations, and placed it in smooth wall tin capsules for liquids $(6 \times 12 \mathrm{~mm}$, Elemental Microanalysis, Devon, UK). For organic carbon content and $\delta^{13} \mathrm{C}$ composition of POC and SOC, GF/F filters and surface sediment samples were subsampled and liquid acidified with $\mathrm{HCl}(1.5 \mathrm{M})$ to remove carbonates. The analyses were performed in triplicates using a Carlo Erba NC2500 elemental analyzer connected via a split interface to a Finnigan MAT Delta Plus mass spectrometer at the Stable Isotope Laboratory of the Department of Geological Sciences at Stockholm University. Some subsamples, after similar preparation steps, were analyzed for its radiocarbon content $\left(\Delta^{14} \mathrm{C}\right)$ at the USNSF National Ocean Sciences Accelerator Mass Spectrometry (NOSAMS) Facility at Woods Hole Oceanographic Institution. Uncertainties of $\Delta^{14} \mathrm{C}, \delta^{13} \mathrm{C}$, and $\mathrm{OC}$ analyses were \pm 0.002 (fraction modern error), $\pm 0.1 \%$, and $\pm 2 \%$ of the measured OC content, respectively.

\subsection{Lignin phenols analysis}

The quantification of lignin-derived phenols in DOC (SPE eluents), POC (Teflon filters), and SOC (surface sediment samples) was performed as described in detail by Louchouarn et al. (2000) and Tesi et al. (2014). Briefly, for the analysis of dissolved lignin, 5-15 mL of elution samples (1$2 \mathrm{mg}$ OC equivalent) were reduced to dryness under a stream of nitrogen in Teflon tubes. The dried samples were then oxidized under alkaline oxygen-free conditions (degassed $\mathrm{NaOH}$ solution, $8 \%$; Goni and Montgomery, 2000) with an
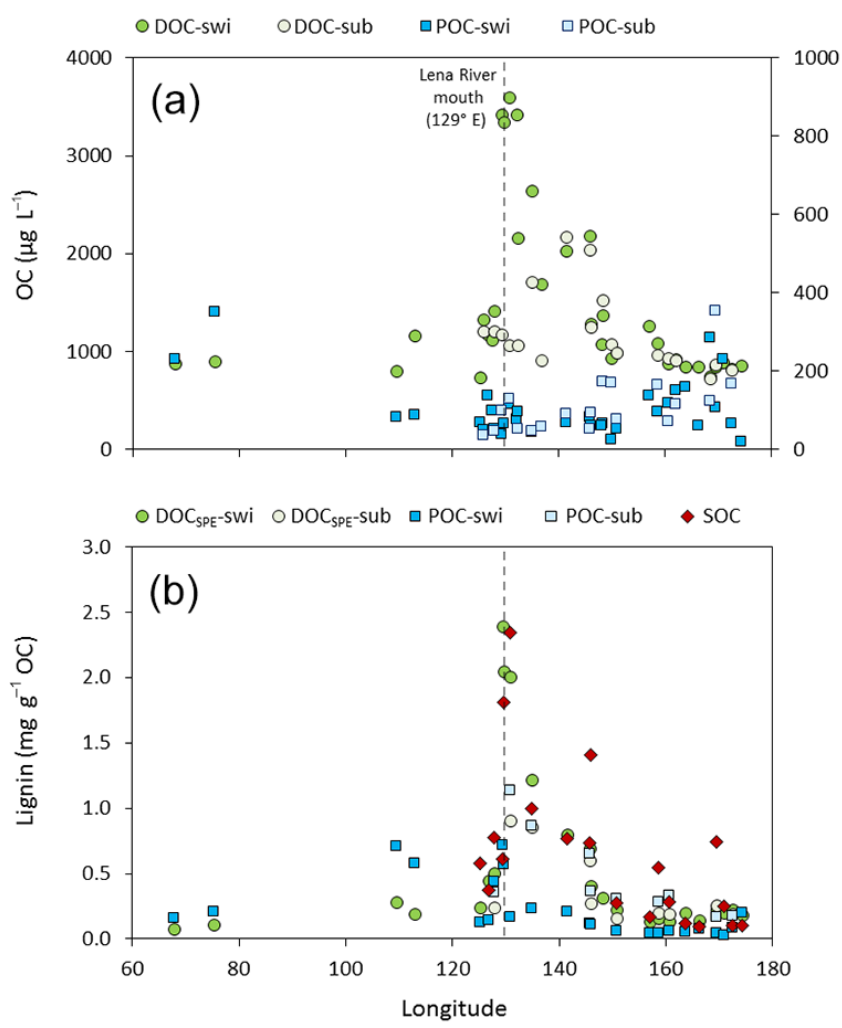

Figure 2. Longitudinal distribution of organic matter content in water and sediment samples. (a) Organic carbon concentrations $\left(\mu \mathrm{g} \mathrm{L}^{-1}\right)$ in DOC (green circles) and POC (blue squares). The left $y$ axis is for DOC and the right $y$ axis for POC. (b) Lignin concentrations $\left(\mathrm{mg} \mathrm{g}^{-1} \mathrm{OC}\right)$ in $\mathrm{DOC}_{\mathrm{SPE}}$ (green circles), POC (blue squares) and SOC (red diamonds); swi: seawater intake samples (surface water samples at $8 \mathrm{~m}$ depth); sub: samples obtained by submersible pump (near-bottom water samples, $5 \mathrm{~m}$ above bottom). Dashed lines indicate the latitude of the Lena River mouth.

addition of $10 \mathrm{mg}$ of glucose to prevent superoxidation of the lignin polymer and spiked with recovery standards (transcinnamic acid and ethyl vanillin). Samples were then acidified, extracted twice with ethyl acetate and concentrated under vacuum at $60^{\circ} \mathrm{C}$. The same oxidation and extraction procedure was also used for POC (Teflon filters) and SOC samples, but without the addition of glucose in sediment samples.

Prior to the analyses, extracts were re-dissolved in pyridine and derivatized. Target compounds were quantified on a gas-chromatograph mass spectrometer (GC-EI-MS, Agilent) using a DB1-MS capillary column $(30 \mathrm{~m} \times 250 \mu \mathrm{m}$, $0.25 \mu \mathrm{m}$ stationary phase thickness, Agilent $\mathrm{J} \& \mathrm{~W}$ ) for separation. Quantification of lignin phenols, benzoic acids, and p-hydroxybenzenes was achieved using the response factors of external standards. All reported concentrations of $\mathrm{CuO}$ oxidation products were reported in $\mathrm{mg}$ of biomarker per g OC. Some sediment samples (SWE-1, SWE-4, SWE-6, SWE14, SWE-23, SWE-24) were also analyzed by Bröder et 
Table 1. Composition of surface and near-bottom DOC samples collected in the outer Eurasian Arctic Shelf.

\begin{tabular}{|c|c|c|c|c|c|c|c|c|c|c|c|c|c|c|c|}
\hline ID & Region & Lat & Long & $\mathrm{DOC}^{1}$ & $\mathrm{C} / \mathrm{N}$ & $\delta^{13} \mathrm{C}$ & $\Delta^{14} \mathrm{C}$ & Lignin $^{2}$ & $\mathrm{~S} / \mathrm{V}$ & $\mathrm{C} / \mathrm{V}$ & $\mathrm{Sd} / \mathrm{Sl}$ & $\mathrm{Vd} / \mathrm{Vl}$ & $3.5 \mathrm{Bd} / \mathrm{V}$ & $\mathrm{Pn} / \mathrm{P}$ & $P / \mathrm{V}$ \\
\hline \multicolumn{16}{|c|}{ DOC-swi ${ }^{3}$} \\
\hline $\mathrm{T}-1$ & KS & 79.8 & 67.9 & 882 & 14 & -24.7 & & 0.1 & 0.4 & 0.5 & 2.6 & 3.1 & 1.2 & 0.1 & 2.6 \\
\hline $\mathrm{T}-2$ & KS & 81.7 & 75.3 & 906 & 15 & -24.6 & & 0.1 & 0.4 & 0.6 & 1.8 & 2.1 & 1.3 & 0.2 & 2.7 \\
\hline $\mathrm{T}-3$ & LS & 81.3 & 109.4 & 809 & 18 & -25.1 & & 0.3 & 0.5 & 0.3 & 1.6 & 1.9 & 0.8 & 0.3 & 1.5 \\
\hline $\mathrm{T}-4$ & LS & 81.0 & 112.9 & 1171 & 18 & -25.4 & & 0.2 & 0.4 & 0.3 & 2.0 & 2.4 & 0.8 & 0.2 & 1.5 \\
\hline 1 & LS & 78.9 & 125.2 & 737 & 18 & -24.9 & -279 & 0.2 & 0.5 & 0.4 & 1.7 & 1.9 & 1.0 & 0.3 & 1.9 \\
\hline 4 & LS & 77.8 & 126.7 & 1183 & 19 & -25.9 & -214 & 0.4 & 0.4 & 0.2 & 2.7 & 2.7 & 0.6 & 0.2 & 1.0 \\
\hline 6 & LS & 77.1 & 127.4 & 1127 & 18 & -26.0 & & & & & & & & & \\
\hline 13 & LS & 76.8 & 125.9 & 1326 & 22 & -26.3 & & & & & & & & & \\
\hline 14 & LS & 76.9 & 127.8 & 1418 & 25 & -26.8 & & 0.5 & 0.4 & 0.2 & 1.7 & 2.0 & 0.4 & 0.3 & 0.9 \\
\hline 23 & LS & 76.2 & 129.3 & 3428 & 43 & -27.8 & & 2.4 & 0.3 & 0.2 & 1.5 & 1.5 & 0.2 & 0.2 & 0.4 \\
\hline 24 & LS & 75.6 & 129.6 & 3347 & 42 & -27.9 & & 2.1 & 0.3 & 0.2 & 1.6 & 1.5 & 0.3 & 0.2 & 0.4 \\
\hline 25 & $\mathrm{LS}$ & 76.0 & 130.7 & 3598 & 43 & -27.9 & -19 & 2.0 & 0.3 & 0.2 & 1.9 & 1.7 & 0.3 & 0.1 & 0.4 \\
\hline 26 & LS & 76.5 & 132.0 & 3428 & 40 & -27.6 & & & & & & & & & \\
\hline 27 & LS & 76.9 & 132.2 & 2159 & 36 & -27.4 & & & & & & & & & \\
\hline 28 & LS & 77.3 & 134.8 & 2650 & 39 & -27.6 & -90 & 1.2 & 0.3 & 0.2 & 1.6 & 1.7 & 0.3 & 0.2 & 0.5 \\
\hline 29 & LS & 77.8 & 136.7 & 1695 & 33 & -27.0 & & & & & & & & & \\
\hline 39 & W-ESS & 77.7 & 141.4 & 2038 & 36 & -27.4 & & 0.8 & 0.3 & 0.2 & 1.7 & 1.4 & 0.5 & 0.2 & 0.6 \\
\hline 40 & W-ESS & 77.6 & 145.8 & 2191 & 36 & -27.2 & & 0.7 & 0.4 & 0.3 & 2.0 & 1.8 & 0.3 & 0.1 & 0.6 \\
\hline 41 & W-ESS & 77.0 & 148.3 & 1373 & 35 & -29.0 & & & & & & & & & \\
\hline 44 & W-ESS & 76.3 & 146.0 & 1289 & 26 & -26.4 & -160 & 0.4 & 0.4 & 0.3 & 1.9 & 1.7 & 0.5 & 0.3 & 1.1 \\
\hline 45 & W-ESS & 76.4 & 148.1 & 1078 & 30 & -26.9 & & 0.3 & 0.5 & 0.4 & 2.8 & 3.0 & 0.7 & 0.2 & 1.4 \\
\hline 46 & W-ESS & 76.4 & 149.9 & 935 & 25 & -26.3 & & & & & & & & & \\
\hline 48 & W-ESS & 76.5 & 150.8 & 995 & 22 & -26.2 & & 0.2 & 0.5 & 0.5 & 2.9 & 3.1 & 1.0 & 0.2 & 1.7 \\
\hline 49 & W-ESS & 76.5 & 156.9 & 1264 & 23 & -25.4 & & 0.1 & 0.6 & 0.5 & 2.8 & 3.6 & 0.9 & 0.1 & 1.9 \\
\hline 50 & W-ESS & 75.8 & 158.5 & 1086 & 21 & -25.3 & -262 & 0.2 & 0.5 & 0.5 & 3.1 & 3.1 & 1.0 & 0.1 & 1.8 \\
\hline 52 & E-ESS & 74.1 & 160.6 & 881 & 24 & -25.3 & -288 & 0.1 & 0.4 & 0.1 & 0.6 & 1.0 & 0.6 & 0.3 & 2.6 \\
\hline 56 & E-ESS & 74.6 & 161.9 & 922 & 21 & -24.9 & & & & & & & & & \\
\hline 57 & E-ESS & 74.4 & 163.7 & 847 & 23 & -24.5 & & 0.2 & 0.7 & 0.9 & 1.3 & 1.8 & 0.9 & 0.2 & 1.9 \\
\hline 58 & E-ESS & 74.4 & 166.2 & 854 & 23 & -24.7 & & 0.1 & 0.5 & 0.5 & 3.5 & 3.8 & 1.3 & 0.1 & 2.2 \\
\hline 59 & E-ESS & 74.4 & 168.5 & 748 & 25 & -25.0 & & & & & & & & & \\
\hline 60 & E-ESS & 73.4 & 169.5 & 853 & 21 & -24.6 & -268 & 0.2 & 0.7 & 0.7 & 1.6 & 1.9 & 0.6 & 0.2 & 1.7 \\
\hline 61 & E-ESS & 74.1 & 170.9 & 890 & 26 & -24.4 & -278 & 0.2 & 0.6 & 0.8 & 2.3 & 2.8 & 1.5 & 0.2 & 2.1 \\
\hline 63 & E-ESS & 74.7 & 172.4 & 823 & 27 & -25.3 & & 0.2 & 0.6 & 0.8 & 1.9 & 2.4 & 0.7 & 0.3 & 1.7 \\
\hline 66 & E-ESS & 75.9 & 174.3 & 862 & 26 & -26.0 & -270 & 0.2 & 0.6 & 0.9 & 1.7 & 2.3 & 0.9 & 0.3 & 1.5 \\
\hline \multicolumn{16}{|c|}{ DOC-sub $^{4}$} \\
\hline 13 & LS & 76.8 & 125.9 & 1208 & 25 & -26.7 & & & & & & & & & \\
\hline 14 & LS & 76.9 & 127.8 & 1216 & 26 & -26.5 & & 0.2 & 0.5 & 0.5 & 2.5 & 2.5 & 0.7 & 0.3 & 1.4 \\
\hline 23 & LS & 76.2 & 129.3 & 1181 & 30 & -27.0 & & & & & & & & & \\
\hline 25 & LS & 76.0 & 130.7 & 1072 & 35 & -27.2 & & 0.9 & 0.4 & 0.4 & 1.4 & 1.2 & 0.4 & 0.3 & 0.7 \\
\hline 27 & LS & 76.9 & 132.2 & 1072 & 30 & -26.3 & & & & & & & & & \\
\hline 28 & LS & 77.3 & 134.8 & 1711 & 36 & -27.4 & -171 & 0.9 & 0.4 & 0.3 & 1.2 & 0.9 & 0.3 & 0.4 & 0.6 \\
\hline 29 & LS & 77.8 & 136.7 & 916 & 33 & -26.6 & & & & & & & & & \\
\hline 39 & W-ESS & 77.7 & 141.4 & 2170 & 46 & -28.6 & & & & & & & & & \\
\hline 40 & W-ESS & 77.6 & 145.8 & 2047 & 36 & -27.6 & & 0.6 & 0.4 & 0.4 & 1.7 & 1.4 & 0.4 & 0.4 & 0.7 \\
\hline 41 & W-ESS & 77.0 & 148.3 & 1526 & 42 & -28.0 & & & & & & & & & \\
\hline 44 & W-ESS & 76.3 & 146.0 & 1259 & 32 & -27.4 & -188 & 0.3 & 0.6 & 0.7 & 1.2 & 1.3 & 0.5 & 0.5 & 1.1 \\
\hline 46 & W-ESS & 76.4 & 149.9 & 1076 & 19 & -25.7 & & & & & & & & & \\
\hline 48 & W-ESS & 76.5 & 150.8 & 991 & 26 & -26.4 & & 0.2 & 0.6 & 0.7 & 2.1 & 2.1 & 0.6 & 0.6 & 1.4 \\
\hline 50 & W-ESS & 75.8 & 158.5 & 973 & 20 & -26.9 & & 0.2 & 0.6 & 0.7 & 1.4 & 1.7 & 0.6 & 0.6 & 1.5 \\
\hline 52 & E-ESS & 74.1 & 160.6 & 938 & 20 & -25.3 & -307 & 0.2 & 0.7 & 0.7 & 1.2 & 1.4 & 0.7 & 0.7 & 1.7 \\
\hline 56 & E-ESS & 74.6 & 161.9 & 911 & 21 & -25.4 & & & & & & & & & \\
\hline 59 & E-ESS & 74.4 & 168.5 & 724 & 20 & -24.9 & & & & & & & & & \\
\hline 60 & E-ESS & 73.4 & 169.5 & 869 & 20 & -25.4 & -366 & 0.3 & 0.7 & 0.7 & 1.2 & 1.4 & 0.6 & 0.6 & 1.6 \\
\hline 63 & E-ESS & 74.7 & 172.4 & 816 & 18 & -24.6 & & 0.2 & 0.7 & 0.7 & 1.1 & 1.4 & 0.6 & 0.6 & 1.8 \\
\hline
\end{tabular}

${ }^{1}$ DOC concentrations $\left(\mu \mathrm{g} \mathrm{L}^{-1}\right) .{ }^{2}$ Lignin OC-normalized concentrations $\left(\mathrm{mg} \mathrm{g}^{-1} \mathrm{OC}\right) .{ }^{3}$ Swi: seawater intake samples (surface water samples at $8 \mathrm{~m}$ depth) ${ }^{4}$ Sub: samples obtained by submersible pump (near-bottom water samples, $5 \mathrm{~m}$ above bottom). 

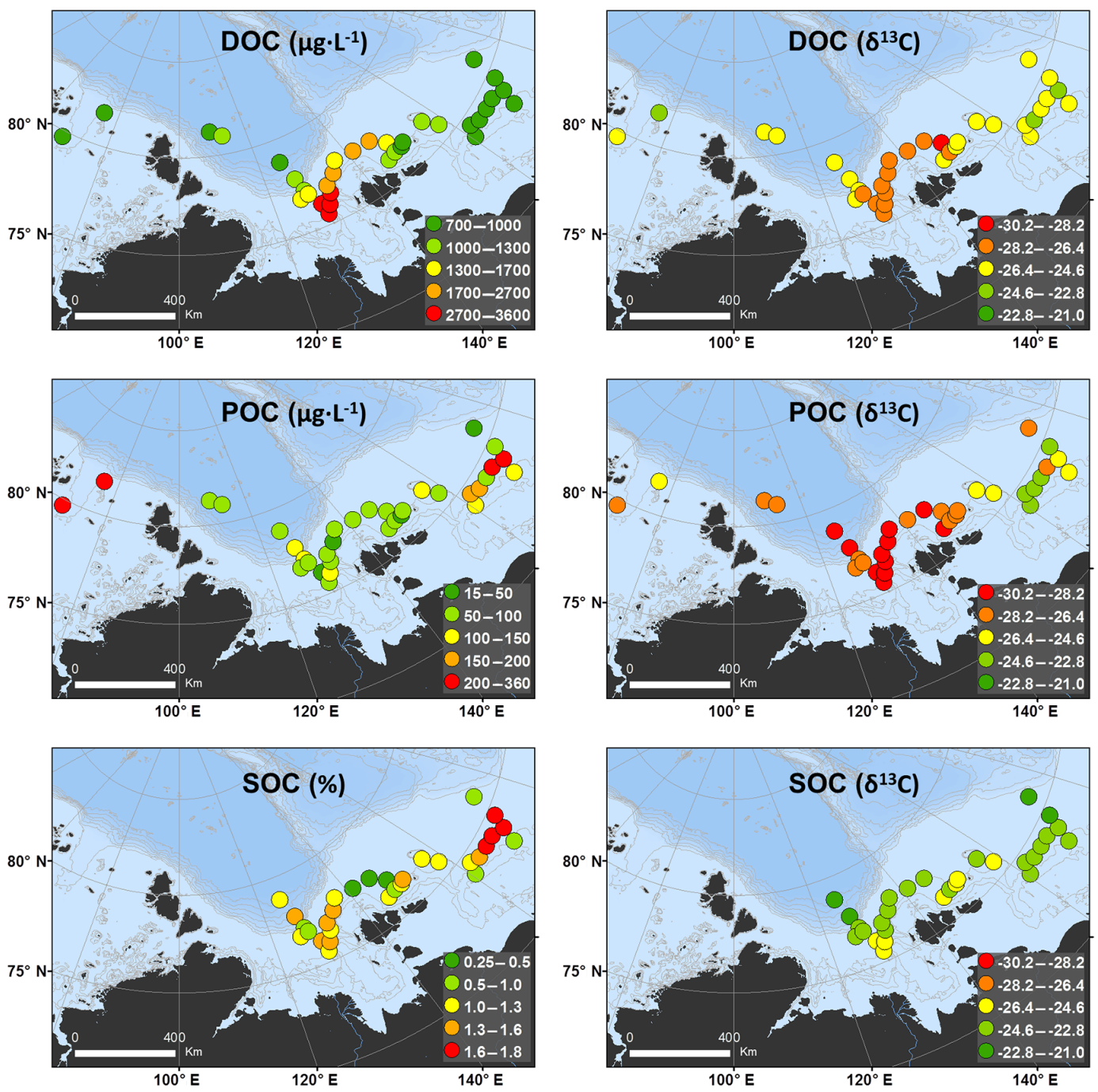

Figure 3. Spatial distribution of organic carbon concentrations and $\delta^{13} \mathrm{C}$ signatures in the DOC, POC (surface water samples at $8 \mathrm{~m}$ depth) and SOC pools of the ESAS.

al. (2016). The small differences in lignin phenols results may stem from the different injections and calibrations used.

\section{Results and discussion}

\subsection{Elemental composition and distribution of DOC, POC and SOC}

DOC in the water column of the outer ESAS during the SWERUS-2014 expedition was 1 order of magnitude higher than POC. The DOC concentrations ranged from 740 to $3600 \mu \mathrm{g} \mathrm{L}{ }^{-1}$ (mean of $1400 \pm 790 \mu \mathrm{g} \mathrm{L}^{-1}$ ) and POC varied between 20 and $360 \mu \mathrm{g} \mathrm{L} \mathrm{L}^{-1}$ (mean of $110 \pm 80 \mu \mathrm{g} \mathrm{L}^{-1}$; Table 1, Figs. 2a, 3). Those values are in the same range as previous studies in the Siberian Arctic seas (Alling et al., 2010; Benner et al., 2005; Sanchez-Garcia et al., 2011).
Whereas DOC showed the highest values in surface waters of the Laptev Sea $\left(2000 \pm 1100 \mu \mathrm{g} \mathrm{L}^{-1}\right)$, particularly off the Lena River mouth, POC concentrations were slightly higher in the Kara Sea $\left(290 \pm 86 \mu \mathrm{gL}^{-1}\right)$ and the E-ESS $\left(150 \pm 92 \mu \mathrm{g} \mathrm{L}^{-1}\right)$ with no significant differences between surface and near-bottom waters. SOC values in surface sediments from the same stations presented higher concentrations in the E-ESS $(1.32 \pm 0.42 \%)$, but also exhibited an increase in the Laptev Sea $(1.21 \pm 0.26 \%$; Fig. 3). This is in the lower range of what was previously reported in the inner shelf of the ESAS (Charkin et al., 2011; Karlsson et al., 2011, 2015; Tesi et al., 2014; Vonk et al., 2012), suggesting either degradation of Terr-OC or sediment sorting during the across-shelf transport as discussed in Tesi et al. (2014) and Bröder et al. (2016). Alternatively, higher POC and SOC values in the E-ESS may be related to the higher marine pro- 
ductivity in that region due to the Pacific water influence (Semiletov et al., 2005; Stein and Macdonald, 2004).

The resulting bulk ratios in the $\mathrm{DOC}_{\mathrm{SPE}}$ fraction indicate terrestrially dominated organic matter sources. The OC / TN ( $\mathrm{TN}=$ organic nitrogen + inorganic nitrogen) of $\mathrm{DOC}_{\mathrm{SPE}}$ ranged between 14 and 43 (mean of $28 \pm 8.4$ ), without significant differences between surface and near-bottom waters (Table 1). Those ratios showed decreasing trends off the Lena River plume with higher ratios in the Laptev Sea and WESS. The same pattern and similar ratios were observed in the inner shelf of the ESAS (Karlsson et al., 2016). Moreover, these values are in the same range as OC / TN ratios of DOC in Eurasian Arctic rivers, which varied between 23 and 69 (Lobbes et al., 2000), and the high OC / TN ratios (>40) of DOC collected from the Kara Sea (Köhler et al., 2003; Opsahl et al., 1999). Marine organic matter has OC / TN values around 6-8 and terrestrial-derived organic matter OC / TN ratios higher than 15 (Baldock et al., 1992; Hedges et al., 1986; Hedges and Oades, 1997). The OC / TN ratios in the particulate and sedimentary compartments were much lower than in the $\mathrm{DOC}_{\mathrm{SPE}}$. Those ratios ranged between 5 and 12 (mean of $7 \pm 1.7$ ) in the POC and from 6 to 8 (mean of $7 \pm 0.5)$ in the SOC. Similar OC / TN values were observed in the inner shelf of the ESAS and Arctic rivers in the particulate fraction (McClelland et al., 2016; Sanchez-Garcia et al., 2011). However, these lower OC / TN ratios are at odds with, e.g., $\delta^{13} \mathrm{C}$-OC and may be influenced by selective degradation of labile carbonaceous forms (Hugelius and Kuhry, 2009), and/or adsorption of inorganic nitrogen (e.g., ammonium) derived from decomposition of organic matter (Sanchez-Garcia et al., 2011; Schubert and Calvert, 2001).

\subsection{Stable carbon and radiocarbon isotopes}

The east-to-west extension of the depleted $\delta^{13} \mathrm{C}$ signatures reflects a strong influence of the Lena River (Fig. 3), both in the Laptev Sea and the ESS. The $\delta^{13} \mathrm{C}$ signatures in the three carbon pools ranged from $-23.9 \pm 1.9 \%$ in the SOC, $-26.1 \pm 1.2 \%$ in the $\mathrm{DOC}_{\mathrm{SPE}}$ and $-27.1 \pm 1.9 \%$ in the POC, with no significant differences between surface and bottom waters (Tables 1, 2 and 3 ). The more depleted $\delta^{13} \mathrm{C}$ POC is consistent with marine productivity using excess dissolved inorganic carbon (DIC) from the Lena River, which is more depleted than marine DIC (Alling et al., 2012; Semiletov et al., 2016). This mechanism also explains similarly depleted $\delta^{13} \mathrm{C}$-POC in the Lena plume far offshore in the Laptev Sea and ESS that matched with depletion of other nutrients (Alling et al., 2010; Sanchez-Garcia et al., 2011). The distribution of $\delta^{13} \mathrm{C}$-SOC was more homogeneous reflecting average over time in the surface sediment regime. Only the concentration of DOC presented a good correlation with $\delta^{13} \mathrm{C}$-DOC ${ }_{\text {SPE }}$ signatures, which indicates that higher concentrations of DOC come from terrigenous sources (Fig. 3).

The radiocarbon ages of $\mathrm{DOC}_{\mathrm{SPE}}$ and $\mathrm{POC}$ showed a depleted and younger trend off the Lena River plume. The
$\Delta^{14} \mathrm{C}$ signals ranged between $-395 \pm 83$ (SOC), $-226 \pm 92$

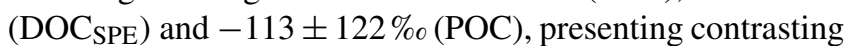
offsets between the Laptev Sea and the East Siberian Sea, particularly in the E-ESS (Tables 1, 2 and 3; Fig. 4). The older and enriched $\delta^{13} \mathrm{C}$ signatures in the outer shelf of the ESS may reflect the influence of sea-ice coverage and the $\mathrm{Pa}-$ cific inflow from the east. We suggest that the sea ice would work as a barrier preventing the direct terrigenous input from inland and reinforcing the influence of Pacific waters. The more enriched $\Delta^{14} \mathrm{C}$ signatures in POC than in DOC are in accordance with previous studies in the Arctic Ocean (Griffith et al., 2012) and the Southern Ocean (Druffel and Bauer, 2000), which reflect likely a dominant marine source in the particulate carbon pool. The radiocarbon signatures in the DOC pool of the outer shelf of the ESAS are older than those observed in the Lena River (>39\%o; Raymond et al., 2007), but younger than or similar to (in the outer and eastern stations) those reported in surface waters of the Canada Basin (<-216\%; Arctic Ocean; Griffith et al., 2012), reflecting the inputs of Pacific waters. The considerable change in age within the DOC pool during the cross-shelf transport is likely due to mixing with older marine DOC. The SOC pool does not present marked west-east distribution of $\Delta^{14} \mathrm{C}$ as observed in $\mathrm{DOC}_{\mathrm{SPE}}$ and POC. The SOC also depicts older signatures near the New Siberian Islands. A recent study from the same area at the land-ocean interface presented older signatures in the POC than in the DOC (Karlsson et al., 2016), suggesting that thawing permafrost was transported preferentially within the POC pool. Therefore, our results support the hypothesis that remobilized permafrost preferentially settles out close to land, and then it is transported off-shelf through sediment resuspension-redeposition events. The older signals in the dissolved fraction of the ice-covered regions are consistent with a more recalcitrant $\mathrm{OC}$ in the dissolved pool of the Arctic Ocean (Follett et al., 2014; Griffith et al., 2012). It seems that the ice extent boundary works as a barrier that prevents the input of young DOC coming from the buoyant freshwater plume of the Lena River (Fig. 4). It is important to point out that near-bottom waters presented more depleted and similar $\Delta^{14} \mathrm{C}$ signatures in both $\mathrm{DOC}_{\mathrm{SPE}}$ and POC $(-258 \pm 94$ and $-250 \pm 83 \%$, respectively) than in surface waters $(-213 \pm 93$ and $-57 \pm 86 \%$ o, respectively; Fig. 5; Tables 1 and 2), suggesting the same older and terrigenous source of OC in both pools. Those contrasting age offsets between surface and near-bottom waters, particularly for the POC fraction, may reflect the off-shelf transport of OC translocated over long distances from thawing permafrost.

DOC was the only carbon pool that presented good correlations with $\Delta^{14} \mathrm{C}$ and $\delta^{13} \mathrm{C}$ data (Fig. 6). Those relationships are consistent with previous observations in the Arctic Ocean (Amon et al., 2012; Benner et al., 2004; Schreiner et al., 2013). The correlation between $\delta^{13} \mathrm{C}$ and DOC $\left(r^{2}=0.68\right)$, with more depleted values for samples with a high DOC concentration, and vice versa, reflects both mixing and the transport of the terrigenous DOC along the shelf. Processes such 
Table 2. Composition of surface and near-bottom POC samples collected in the outer Eurasian Arctic Shelf.

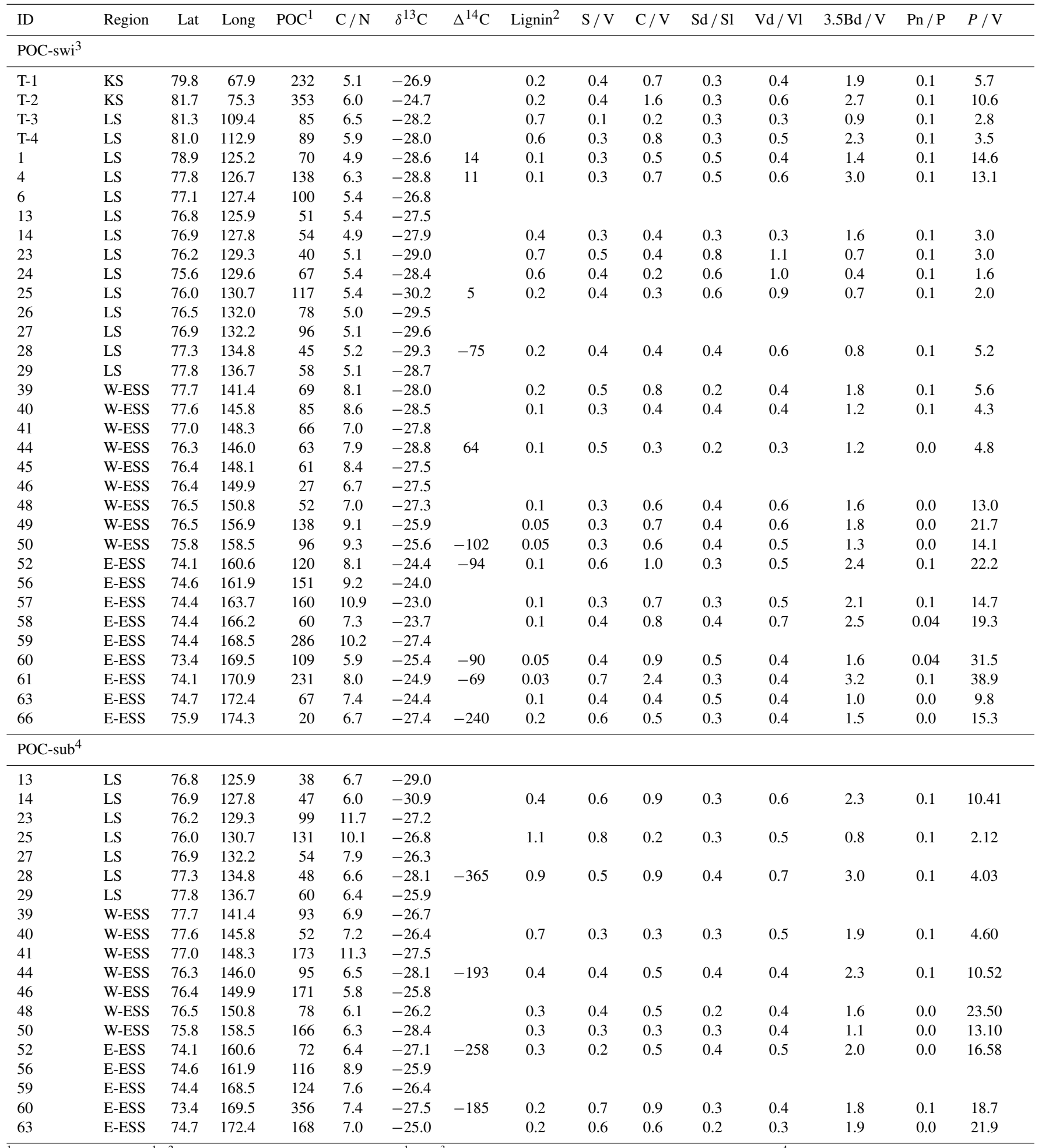

${ }^{1}$ POC concentrations $\left(\mu \mathrm{g} \mathrm{L}^{-1}\right) .{ }^{2}$ Lignin OC-normalized concentrations $\left(\mathrm{mg} \mathrm{g}^{-1} \mathrm{OC}\right) .{ }^{3}$ Swi: seawater intake samples (surface water samples at $8 \mathrm{~m}$ depth). ${ }^{4}$ Sub: samples obtained by submersible pump (near-bottom water samples, $5 \mathrm{~m}$ above bottom). 

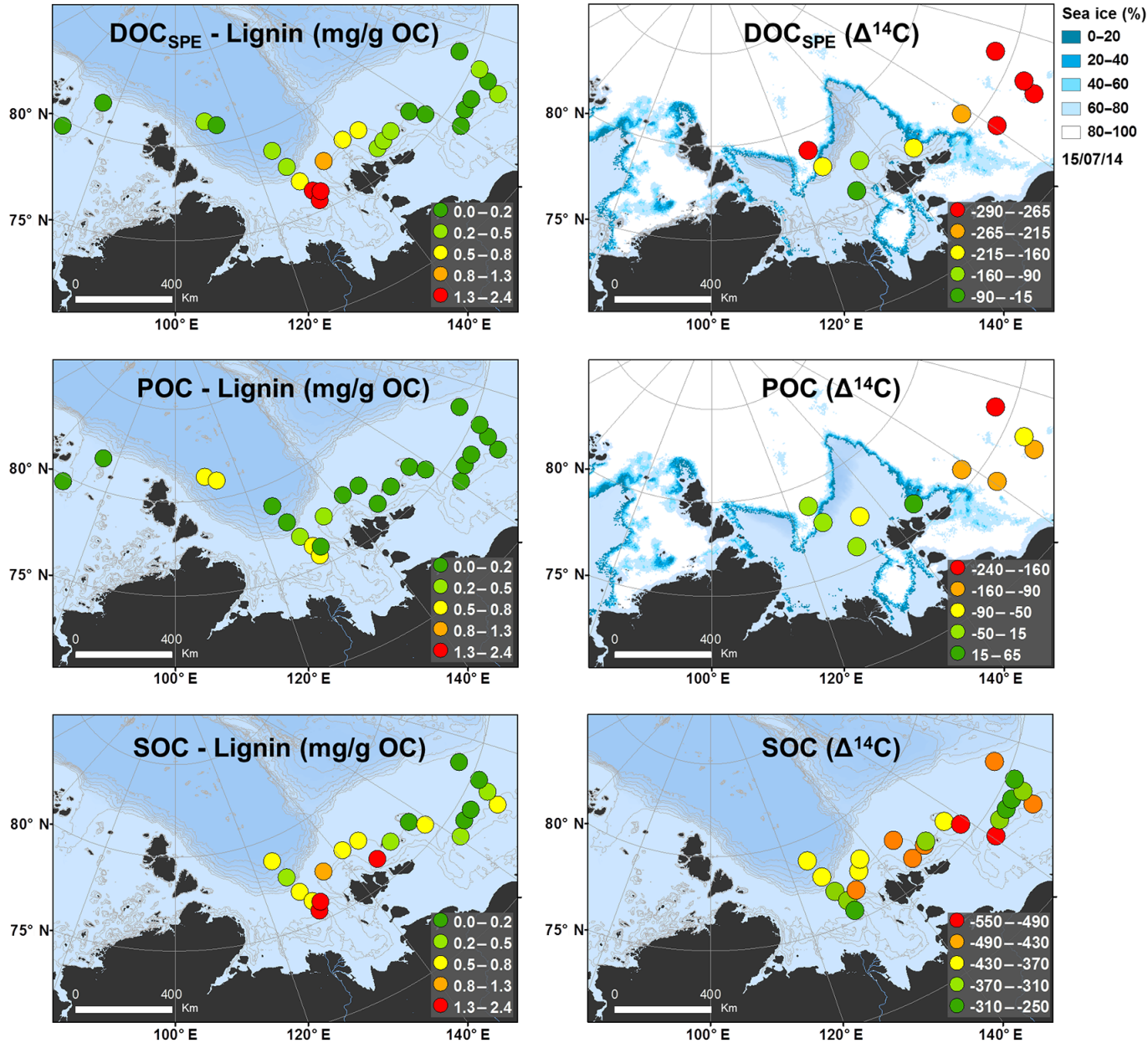

Figure 4. Spatial distribution of lignin $\left(\mathrm{mg} \mathrm{g}^{-1} \mathrm{OC}\right.$ ) and $\Delta^{14} \mathrm{C}$ signatures in the $\mathrm{DOC}_{\mathrm{SPE}}$, POC (surface water samples at $8 \mathrm{~m}$ depth) and SOC pools of the ESAS. Sea ice (\%) during the first sampling day in the ESAS (15 July 2015).

as hydrodynamic sorting, deposition, resuspension and uptake by primary production may contribute to the dispersal and processing of the $\mathrm{OC}$ in the ESAS. On the other hand, the relationship between $\Delta^{14} \mathrm{C}$ and DOC $\left(r^{2}=0.87\right)$ represents both mixing and the source of the terrigenous DOC, where samples with higher DOC concentrations are composed by young Terr-OC and lower DOC concentrations by old and refractory Terr-OC. Overall, these findings are direct evidence that a large proportion of DOC exported to the outer shelf comes from young and fresh vascular plant material.

\subsection{Lignin-derived phenols}

Lignin-derived phenols are exclusively synthesized by vascular plants and account for one third of the organic matrix of wood, grasses, needles, and herbage; therefore, they have been extensively used to characterize the pathway of terrestrial matter in the marine environment (Louchouarn et al., 1999; Pasqual et al., 2013; Tesi et al., 2014). The carbonnormalized lignin content $\left(\mathrm{mg} \mathrm{g}^{-1} \mathrm{OC}\right)$ refers to the sum of vanillyl, syringyl and cinnamyl phenols. DOC $\mathrm{SPE}$ samples presented lignin concentration on the same order as the corresponding underlying sediments $(0.10-2.34$ and 0.08 $2.40 \mathrm{mg} \mathrm{g}^{-1} \mathrm{OC}$, respectively). By contrast, the particulate carbon pool had slightly lower OC-normalized lignin concentrations between 0.03 and $1.14 \mathrm{mg} \mathrm{g}^{-1} \mathrm{OC}$ (Fig. 4; Tables 1 and 2). Some surface POC samples, the ones in the Kara Sea, showed more lignin than in the DOC, but those concentrations were relatively low compared to the higher lignin yields observed in the dissolved and sedimentary OC pools from the ESAS. Lignin levels are relativity small when compared to the actual river/coastal erosion input (Amon et al., 2012; Lobbes et al., 2000), but in the same range to lignin values in SOC and DOC pools from previous studies in ESAS sediments (Karlsson et al., 2015; Tesi et al., 2014) and the polar surface water of the Arctic Ocean (Benner et al., 2005). These are the first POC-lignin data in the Arctic Ocean. Lignin concentrations exhibited contrasting offsets between surface and near-bottom waters, particularly in the POC pool. $\mathrm{DOC}_{\mathrm{SPE}}$ presented similar lignin concen- 
Table 3. Composition of surface sediment samples collected in the outer Eurasian Arctic Shelf.

\begin{tabular}{|c|c|c|c|c|c|c|c|c|c|c|c|c|c|c|c|c|}
\hline ID & Region & Lat & Long & Depth $^{1}$ & SOC $^{2}$ & $\mathrm{C} / \mathrm{N}$ & $\delta^{13} \mathrm{C}$ & $\Delta^{14} \mathrm{C}$ & Lignin $^{3}$ & $\mathrm{~S} / \mathrm{V}$ & $\mathrm{C} / \mathrm{V}$ & $\mathrm{Sd} / \mathrm{Sl}$ & $\mathrm{Vd} / \mathrm{Vl}$ & $3.5 \mathrm{Bd} / \mathrm{V}$ & $\mathrm{Pn} / \mathrm{P}$ & $P / \mathrm{V}$ \\
\hline \multicolumn{17}{|c|}{ SOC } \\
\hline $1^{4}$ & LS & 78.9 & 125.2 & -3120 & 1.0 & 7.1 & -22.3 & -418 & 0.6 & 0.7 & 0.3 & 0.6 & 0.9 & 0.6 & 0.1 & 1.6 \\
\hline $4^{4}$ & LS & 77.8 & 126.7 & -2186 & 1.3 & 6.8 & -22.5 & -428 & 0.4 & 0.6 & 0.4 & 1.0 & 1.3 & 1.3 & 0.1 & 2.2 \\
\hline 6 & LS & 77.1 & 127.4 & -92 & 0.8 & 6.7 & -23.2 & & & & & & & & & \\
\hline 13 & LS & 76.8 & 125.9 & -74 & 1.3 & 7.4 & -24.1 & & & & & & & & & \\
\hline 14 & LS & 76.9 & 127.8 & -64 & 0.9 & 6.4 & -24.3 & -314 & 0.8 & 0.6 & 0.2 & 0.9 & 1.2 & 0.7 & 0.1 & 1.6 \\
\hline 23 & LS & 76.2 & 129.3 & -56 & 1.6 & 7.6 & -25.0 & -333 & 0.6 & 0.5 & 0.2 & 1.0 & 1.3 & 0.7 & 0.1 & 1.5 \\
\hline 24 & LS & 75.6 & 129.6 & -46 & 1.1 & 6.9 & -24.8 & -284 & 1.8 & 0.6 & 0.3 & 1.0 & 1.3 & 0.5 & 0.2 & 1.1 \\
\hline 25 & LS & 76.0 & 130.7 & -53 & 1.6 & 8.4 & -25.5 & & 2.4 & 0.6 & 0.3 & 0.8 & 1.0 & 0.3 & 0.2 & 0.9 \\
\hline 26 & LS & 76.5 & 132.0 & -52 & 1.2 & 7.9 & -24.4 & -441 & & & & & & & & \\
\hline 27 & LS & 76.9 & 132.2 & -44 & 1.4 & 7.5 & -24.2 & & & & & & & & & \\
\hline 28 & LS & 77.3 & 134.8 & -49 & 1.4 & 7.1 & -23.8 & -421 & 1.0 & 0.5 & 0.3 & 1.1 & 1.4 & 0.6 & 0.1 & 1.4 \\
\hline 29 & LS & 77.8 & 136.7 & -57 & 1.1 & 6.9 & -23.4 & -427 & & & & & & & & \\
\hline 39 & W-ESS & 77.7 & 141.4 & -45 & 0.5 & 7.9 & -24.0 & & 0.8 & 0.5 & 0.2 & 0.9 & 1.2 & 0.6 & 0.1 & 1.4 \\
\hline 40 & W-ESS & 77.6 & 145.8 & -47 & 0.4 & 7.1 & -23.7 & -457 & 0.7 & 0.6 & 0.2 & 1.0 & 1.3 & 0.7 & 0.1 & 1.7 \\
\hline 41 & W-ESS & 77.0 & 148.3 & -40 & 0.3 & 7.7 & & & & & & & & & & \\
\hline 44 & W-ESS & 76.3 & 146.0 & -43 & 1.2 & 7.9 & -24.8 & -484 & 1.4 & 0.6 & 0.4 & 0.7 & 1.0 & 0.5 & 0.2 & 1.4 \\
\hline 45 & W-ESS & 76.4 & 148.1 & -40 & 1.0 & 7.7 & -24.4 & & & & & & & & & \\
\hline 46 & W-ESS & 76.4 & 149.9 & -40 & 1.1 & 7.2 & -24.7 & -463 & & & & & & & & \\
\hline 48 & W-ESS & 76.5 & 150.8 & -40 & 1.4 & 7.4 & -25.8 & -345 & 0.3 & 0.5 & 0.3 & 1.2 & 1.2 & 1.3 & 0.1 & 3.8 \\
\hline 49 & W-ESS & 76.5 & 156.9 & -47 & 1.3 & 6.6 & -23.6 & -375 & 0.2 & 0.6 & 0.3 & 1.3 & 2.0 & 1.9 & 0.1 & 6.3 \\
\hline 50 & W-ESS & 75.8 & 158.5 & -44 & 1.2 & 6.7 & -24.6 & -523 & 0.5 & 0.5 & 0.2 & 0.9 & 1.2 & 0.7 & 0.1 & 2.0 \\
\hline 52 & E-ESS & 74.1 & 160.6 & -46 & 0.8 & 7.1 & -23.9 & -550 & 0.3 & 0.4 & 0.2 & 0.8 & 0.9 & 0.9 & 0.1 & 3.3 \\
\hline 56 & E-ESS & 74.6 & 161.9 & -48 & 1.1 & 7.3 & -23.7 & & & & & & & & & \\
\hline 57 & E-ESS & 74.4 & 163.7 & -52 & 1.6 & 7.0 & -24.2 & -326 & 0.1 & 0.6 & 0.3 & 0.8 & 1.1 & 1.9 & 0.1 & 7.6 \\
\hline 58 & E-ESS & 74.4 & 166.2 & -54 & 1.7 & 7.5 & -23.8 & -296 & 0.1 & 0.7 & 0.5 & 0.8 & 1.4 & 2.4 & 0.1 & 13.3 \\
\hline 59 & E-ESS & 74.4 & 168.5 & -54 & 1.7 & 6.7 & 23.5 & -3307 & & & & & & & & \\
\hline 60 & E-ESS & 73.4 & 169.5 & -343 & 0.9 & 7.6 & -3324.0 & -3472 & 0.7 & 1.0 & 0.6 & 0.7 & 0.8 & 0.5 & 0.1 & 2.9 \\
\hline 61 & E-ESS & 74.1 & 170.9 & -51 & 1.8 & 7.0 & -24.2 & -318 & 0.3 & 0.9 & 0.8 & 0.9 & 1.0 & 0.9 & 0.1 & 5.3 \\
\hline 63 & E-ESS & 74.7 & 172.4 & -64 & 1.7 & 7.3 & -22.7 & -251 & 0.1 & 0.8 & 0.8 & 0.7 & 1.1 & 1.9 & 0.1 & 11.3 \\
\hline $66^{4}$ & E-ESS & 75.9 & 174.3 & -239 & 0.8 & 5.6 & -21.0 & -448 & 0.1 & 0.8 & 0.4 & 0.3 & 0.5 & 1.4 & 0.1 & 8.4 \\
\hline
\end{tabular}

${ }^{1}$ Water depth (m). ${ }^{2}$ Percentage of sedimentary organic carbon. ${ }^{3}$ Lignin OC-normalized concentrations $\left(\mathrm{mg} \mathrm{g}^{-1} \mathrm{OC}\right) .{ }^{4}$ Cores sectioned on high resolution $(0.5 \mathrm{~cm}$ intervals).

trations in surface and near-bottom waters, except for the more concentrated samples closer to the Lena River mouth. Conversely, POC showed enhanced levels in all near-bottom water samples (from 0.17 to $1.14 \mathrm{mg} \mathrm{g}^{-1} \mathrm{OC}$ ), with even higher concentrations than in the dissolved pool (from 0.16 to $0.91 \mathrm{mg} \mathrm{g}^{-1} \mathrm{OC}$; Fig. 2b; Tables 1 and 2). Those vertical lignin dissimilarities in the water column were not observed in the total OC of the dissolved and particulate fractions. However, $\Delta^{14} \mathrm{C}$-OC also showed offsets in the particulate pool. While DOC $\mathrm{SPE}_{\mathrm{S}}$ depicted similar $\Delta^{14} \mathrm{C}$ signatures in both surface and near-bottom waters (Fig. 5b), POC was much older in near-bottom waters (Fig. 5a). Hence, these findings suggest that particulate old OC with high concentrations of lignin, probably coming from thawing permafrost, is mainly transported off-shelf in near-bottom waters by resuspension and remobilization of the SOC pool.

Lignin phenols exhibited decreasing OC-normalized concentrations with increasing distance from the Lena River plume in the DOC and SOC pools and in both surface and near-bottom waters (Fig. 4). Previous studies in ESAS for other biomarkers have also reported decreasing across-shelf trends of terrestrial organic matter with increasing distance from the coast (Selver et al., 2015; Tesi et al., 2014). Several studies reported minimal degradation of DOC across the broad Eurasian shelves (Dittmar and Kattner, 2003b; Kattner et al., 1999; Köhler et al., 2003). With such a scenario, our off-shelf decreasing lignin concentrations in DOC, POC and SOC pools may be interpreted to result from dilution with marine organic matter during transport and/or hydrodynamic sorting along the water and sediment dispersal system. However, other studies found that terrestrial DOC in this ESAS shelf sea system was degraded, with a first-order removal rate constant of $0.3 \mathrm{yr}^{-1}$ (Alling et al., 2010). Recent studies also suggested high reactivity of lignin in rivers (Benner and Kaiser, 2011; Fichot and Benner, 2014; Ward et al., 2013) and in an offshoreward direction across ESAS (Bröder et al., 2016; Tesi et al., 2014). If this instead is the dominating process, the decreasing trend in the current study may also be due to degradation.

Our results depicted a strong positive relationship between lignin phenols and total dissolved organic content within the 35 DOC $_{\text {SPE }}$ samples analyzed along the outer ESAS $(r=0.89$; Fig. 7). There were also significant correlations between OC-normalized concentrations of lignin phenols and $\delta^{13} \mathrm{C}(r=0.66)$ and $\Delta^{14} \mathrm{C}(r=0.78)$ in the $\mathrm{DOC}_{\mathrm{SPE}}$ pool. These data are consistent with the modern radiocarbon ages of DOC observed in Arctic rivers (Benner et al., 2004, 2005; Karlsson et al., 2016), which also demonstrated a gen- 

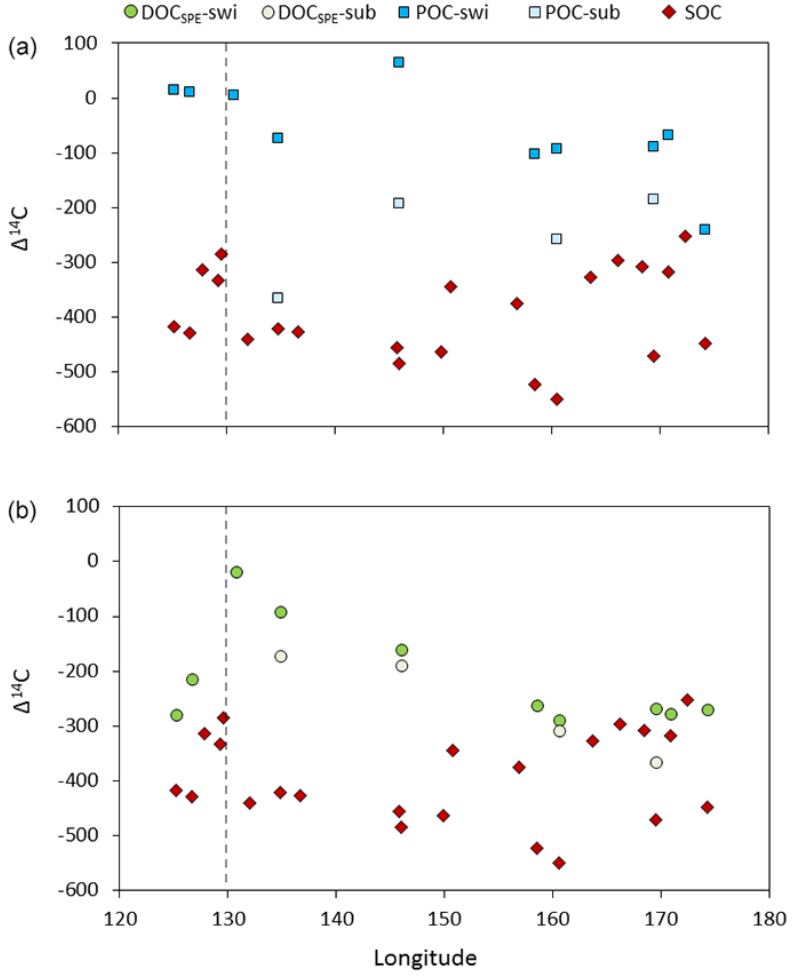

Figure 5. Longitudinal distribution of $\Delta^{14} \mathrm{C}$ signatures in $\mathrm{DOC}_{\mathrm{SPE}}$ (green circles), POC (blue squares) and SOC (red diamonds); swi: seawater intake samples (surface water samples at $8 \mathrm{~m}$ depth); sub: samples obtained by submersible pump (near-bottom water samples, $5 \mathrm{~m}$ above bottom). Dashed lines indicate the latitude of the Lena River mouth.

eral agreement between lignin phenols and $\Delta^{14} \mathrm{C}$ signatures as traces of terrigenous DOC. Lignin phenols were found in old OC from permafrost (Tesi et al., 2014). Compoundspecific radiocarbon analyses of lignin phenols from sediments off major river mouths in ESAS indicated that those macromolecules were younger than sedimentary bulk OC (Feng et al., 2013). This is consistent with lignin compounds derived from both sources, and the higher lignin content from younger $\mathrm{DOC}_{\mathrm{SPE}}$ likely coming from either recently produced vascular plant material or from contemporary topsoil.

By contrast, the slightly negative correlation between lignin phenols and $\Delta^{14} \mathrm{C}$ signatures in POC $(r=0.53$; Fig. 7), with higher lignin concentrations in older POC, suggests that those macromolecules are coming from remobilized older permafrost carbon. Those results are consistent with previous findings indicating that $\mathrm{OC}$ from thawed permafrost is transported preferentially within the particulate carbon pool (Karlsson et al., 2016). There was no relationship between lignin content and bulk POC and SOC, which suggests that both pools are composed of a mixture of marine and terrestrial organic carbon. Taken together, whereas "young" Terr-OC is transported mainly within the surface
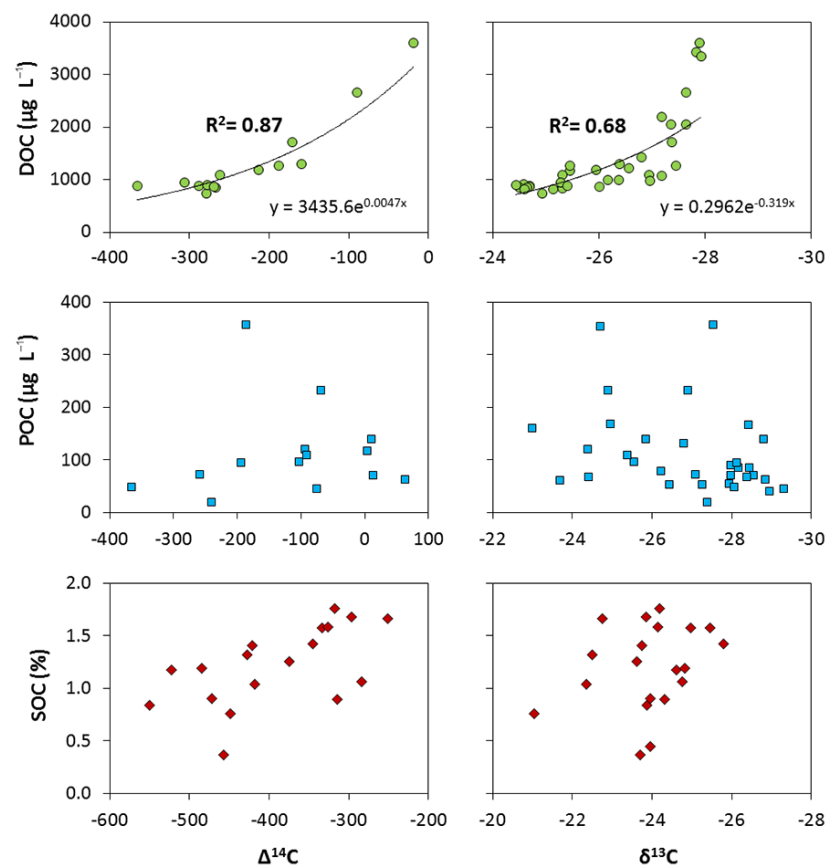

Figure 6. Relationships between organic carbon and $\Delta^{14} \mathrm{C}$ and $\delta^{13} \mathrm{C}$ signatures in the DOC (green circles), POC (blue squares) and SOC (red diamonds).

dissolved fraction, near-bottom POC and SOC carries offshelf preferentially old OC from remobilized permafrost.

\subsection{Biomarker indications of sources of DOC, POC and SOC}

The ratios of individual or classes of lignin phenols are frequently used to infer the types of plants yielding the phenols and to what extent the organic matter has been oxidized. Vanillyl phenols (vanillin, acetovanillone and vanillic acid) are ubiquitous in lignin, while syringyl phenols (syringaldehyde, acetosyringone and syringic acid) derive only from angiosperms (Hedges and Mann, 1979; Spencer et al., 2008). Ratios of syringyl to vanillyl (S / V) phenols indicate contribution of angiosperm and gymnosperm vegetation to TerrOC. Our low S / V ratios (from 0.14 to 1.05 ) indicate gymnosperm vegetation as the most important source of lignin (Fig. 8a; Tables 1, 2 and 3). However, the high S / V ratios in the easternmost samples, particularly within the DOC and SOC, reflect a higher source apportion of tundra plants (Lobbes et al., 2000). Elevated values of S / V were also reported in sediments and dissolved organic carbon from the inner shelf of the same study area (Karlsson et al., 2016; Tesi et al., 2014). The fact that the Indigirka and Kolyma watersheds are north of the Arctic Circle with a general shift to flowering tundra plants could explain the elevated S / V ratios in the E-ESS.

Cinnamyl phenols ( $p$-coumaric acid, ferulic acid) are predominantly found in herbaceous tissues, and the ratio cin- 

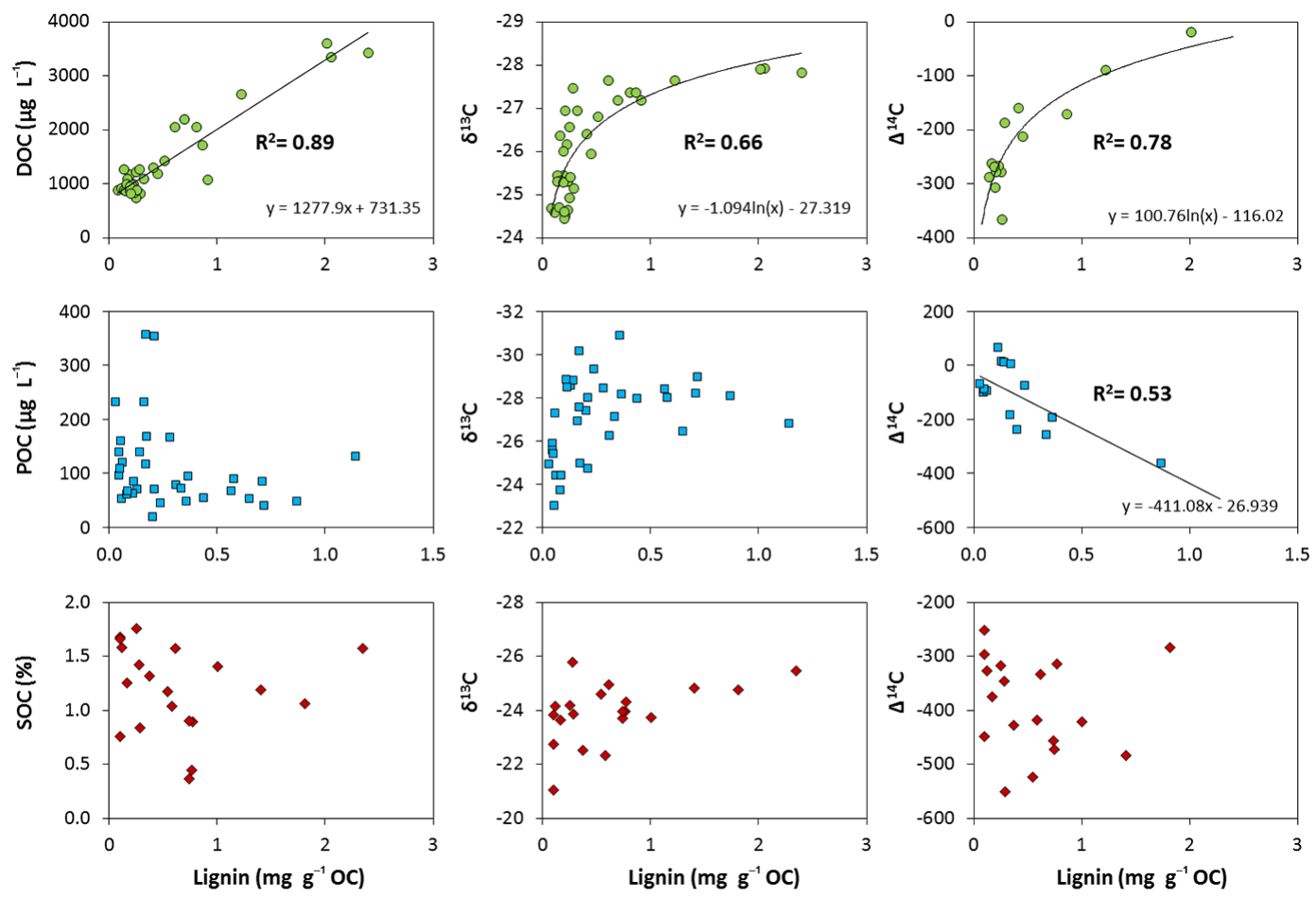

Figure 7. Correlations between lignin concentrations ( $\mathrm{mg} \mathrm{g}^{-1} \mathrm{OC}$ ) and organic carbon, $\delta^{13} \mathrm{C}$ and $\Delta^{14} \mathrm{C}$ signatures in DOC (green circles), POC (blue squares) and SOC (red diamonds).

namyl over vanillyl $(\mathrm{C} / \mathrm{V})$ has been used to distinguish woody lignin from other sources (Goni and Hedges, 1992; Hedges and Mann, 1979). C / V ratios did not show a specific trend along the east-to-west data set. Similar results were observed previously in inner-shelf sediments and in the colloidal DOC fraction from the ESAS (Karlsson et al., 2016). As we also analyzed lignin phenols in the particulate fraction, we could see that $\mathrm{C} / \mathrm{V}$ ratios were slightly higher in POC $(0.64 \pm 0.42)$ than in SOC $(0.37 \pm 0.18$; Tables 1,2 and 3), possibly reflecting more herbaceous plants or sphagnum moss source in the particulate pool and more woody lignin in the sedimentary carbon. Those ratios should always be carefully interpreted as photooxidation and microbial degradation can alter the original compositions (Hedges and Prahl, 1993; Opsahl and Benner, 1995). However, degradation lowers both S / V and C / V ratios, but mostly C / V. If degradation was indeed the main process we would expect a correlation between S / V and C / V. Therefore, while some degradation cannot be excluded, the observed differences in lignin phenols between carbon pools likely reflect a different source. Regarding the classical source plot of S / V vs. C / V, our data set distributes along a line between angiosperm leaves and grasses and gymnosperm wood, suggesting that little amounts of non-woody angiosperm tissues are mixing with large amounts of gymnosperm woods in these samples (Fig. 8a). Overall, this plot underlines distinct clustering between OC pools, suggesting that angiosperms are mainly transported by SOC and gymnosperms by POC.

$p$-Hydroxybenzoic acids $(P)$ can originate from different sources, while $p$-hydroxyacetophenone (Pn) has only been detected in terrigenous organic matter, particularly in peat and sphagnum (Williams et al., 1998), while $p$ hydroxybenzaldehyde $(\mathrm{Pl})$ and $p$-hydroxybenzoic acid $(\mathrm{Pd})$ can also derive from marine sources (Goni and Hedges, 1995). The Pn / $P$ ratios observed in DOC (0.08-0.37), SOC $(0.06-0.17)$ and POC $(0.02-0.14)$ suggest that the OC in the dissolved pool contains a larger terrestrial component than in the particulate and sediment pools (Tables 1, 2 and 3). Those ratios present a slight east-to-west trend with higher values off the Lena River plume. Similar trends and results were observed by Karlsson et al.(2016) in the colloidal OC along the ESAS coast (0.15-30). Amon et al. (2012) characterized the chemical composition of DOC in Arctic rivers and reported $\mathrm{Pn} / P$ ratios in the same range; for instance, those ratios in the Lena, Indigirka and Kolyma rivers varied between 0.30 and 0.39 . Further, $P / \mathrm{V}$ ratios presented an opposite trend to $\mathrm{Pn} / P$ ratios with much higher values in the POC $(11.9 \pm 9)$ than in the DOC $(1.4 \pm 0.6)$ and SOC pools $(4 \pm 3.6$; Tables $1,2,3)$. These ratios are in agreement with the relationships of DOC and $\Delta^{14} \mathrm{C}$ and $\delta^{13} \mathrm{C}$ presented above, which indicate that the DOC exported off-shelf is mainly "young" and terrestrial. Nevertheless, it is important to note that these proxies should be interpreted carefully as $P$ products account 

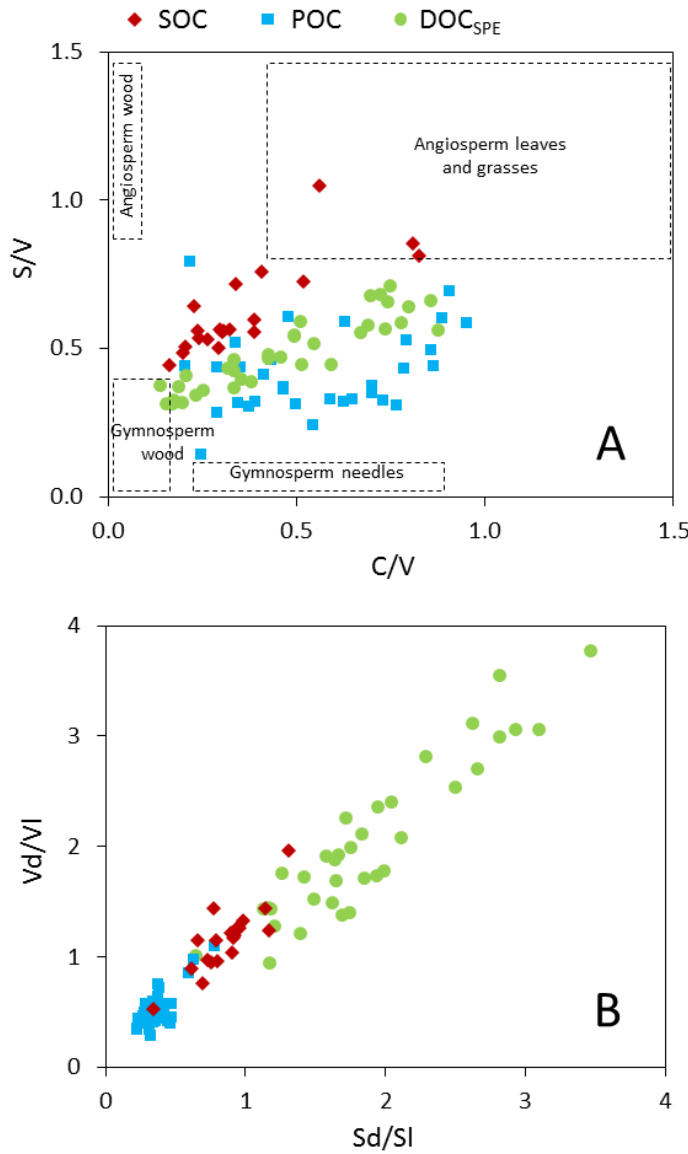

Figure 8. Lignin/phenol ratios in $\mathrm{DOC}_{\mathrm{SPE}}$ (green circles), POC (blue squares) and SOC (red diamonds). (a) Classical source plot of syringyl / vanillyl (S / V) vs. cinnamyl / vannillyl (C / V). Typical ranges for woody and non-woody tissues of both angiosperm and gymnosperm vegetation are indicated as boxes in the graph (Goñi et al., 2000). (b) The acid/aldehyde ratios of syringyl ( $\mathrm{Sd} / \mathrm{Sl}$ ) vs. vanillyl $(\mathrm{Vd} / \mathrm{Vl})$.

for less than $0.1-0.2 \%$ of the bulk OC, and in some samples the particulate and sedimentary pools have more lignin yield than the dissolved OC.

\subsection{Indicators of Terr-OC degradation across the $\mathrm{OC}$ continuum}

The relative abundances of some lignin phenols provide information about the diagenetic alteration of Terr-OC. The acid/aldehyde ratios of syringyl $(\mathrm{Sd} / \mathrm{Sl})$ and vanillyl $(\mathrm{Vd} / \mathrm{Vl})$ have been utilized as indicators of the relative degradation of the plant matter contribution, as aldehydes degrade faster than corresponding acids (Goni and Hedges, 1992; Hedges et al., 1986). However, some caution should be applied in the interpretation as source signals are more varied than originally thought, and fractionation occurs during leaching/adsorption processes (Benner et al., 1990; Hernes et al., 2007). Our data showed $\mathrm{Sd} / \mathrm{Sl}$ and Vd/Vl ratios
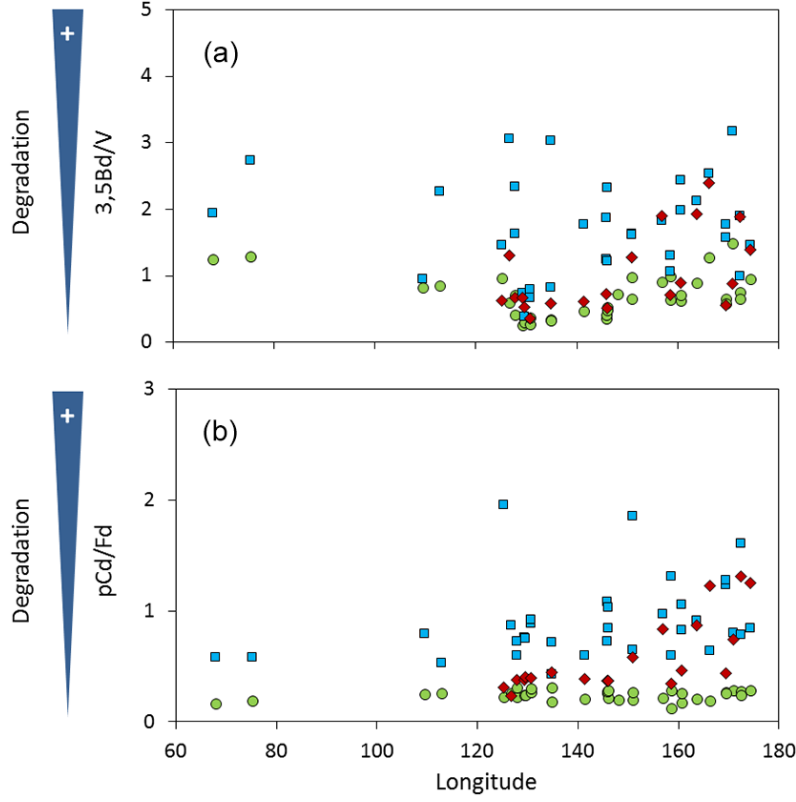

Figure 9. Lignin proxies of Terr-OC and relative degradation state

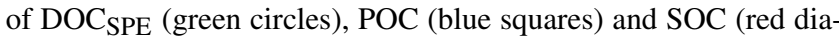
monds). (a) Ratios between 3,5-dihydroxybenzoic acid and vanillyl phenols (3,5-Bd / V). (b) Ratios between $p$-coumaric acid and ferulic acid $(p \mathrm{Cd} / \mathrm{Fd})$.

higher in $\mathrm{DOC}_{\mathrm{SPE}}(1.9 \pm 0.6$ and $2.0 \pm 0.7$, respectively), than in SOC $(0.9 \pm 0.2$ and $1.1 \pm 0.3)$ and POC $(0.4 \pm 0.1$ and $0.5 \pm 0.2$ ), indicating the presence of highly oxidized lignin in the dissolved pool (Tables 1, 2 and 3; Fig. 8b). It is important to notice that the ranges of $\mathrm{Sd} / \mathrm{Sl}$ and $\mathrm{Vd} / \mathrm{Vl}$ ratios in this study were relatively broad and with clear clusters between carbon pools. POC ratios were lower than the underlying sediments and the dissolved carbon pool presented very high ratios (Fig. 8b). Those ratios are in accordance with global studies on POC (Hernes and Benner, 2002; Lobbes et al., 2000; Winterfeld et al., 2015), sediments (Goni and Montgomery, 2000; Goni et al., 2005; Tesi et al., 2014) and DOC (Amon et al., 2012; Hernes and Benner, 2002; Lobbes et al., 2000), which also found higher ratios in the dissolved than in the particulate phase. The elevated Sd / S1 and $\mathrm{Vd} / \mathrm{Vl}$ in the dissolved fraction, as well as the enhanced ratios in the SOC pool, may reflect leaching/adsorption processes (Hernes et al., 2007; Houel et al., 2006).

Another proxy commonly used to determine the degradation of Terr-OC is the ratio between 3,5-dihydroxybenzoic acid and vanillyl phenols (3,5-Bd / V; Farella et al., 2001; Houel et al., 2006; Otto and Simpson, 2006; Prahl et al., 1994). Since 3,5-Bd is highly resistant to degradation (Dickens et al., 2007) while vanillyl phenols are very susceptible to degradation, higher values of 3,5-Bd / V are indicative of more degraded Terr-OC. Our results presented opposite patterns than the ones observed by $\mathrm{Sd} / \mathrm{Sl}$ and $\mathrm{Vd} / \mathrm{Vl}$ with higher $3,5-\mathrm{Bd} / \mathrm{V}$ ratios in POC $(1.7 \pm 0.7)$ and SOC 
$(1.0 \pm 0.6)$ and lower ratios in $\mathrm{DOC}_{\mathrm{SPE}}(0.7 \pm 0.3$; Tables 1 , 2 and 3 ; Fig. 9b). These values are in accordance with those in DOC from ESAS rivers (0.4-0.7; Amon et al., 2012) and the colloidal fraction from the ESAS land-ocean interface (0.4-0.8; Karlsson et al., 2016). In addition, SOC ratios are consistent with those observed in surficial sediments from the same area (0.2-1.3; Tesi et al., 2014). However, we could not find previous studies to compare our 3,5-Bd / V ratios in POC. The higher ratios in POC suggest that Terr-OC is more degraded in the particulate fraction than in the other carbon pools of the outer ESAS. We should also consider that those ratios could support the role of a source change as observed with S / V and C / V proxies, and macroalgal sources of 3,5-Bd might be significant in selected marine systems comprising minimal fractions of terrigenous organic matter (Goni and Hedges, 1995). The 3,5-Bd / V ratios in DOC $\mathrm{SPE}_{\text {, }}$ POC and SOC depicted a slightly increasing tendency in the eastern samples (Fig. 9b). Previous studies in sediments and the colloidal fraction from the ESAS also reported the same trend (Karlsson et al., 2016; Tesi et al., 2014), reflecting the Pacific inflow from the east of more marine and/or degraded OC. We consider in our study that this degradation proxy is more reliable than $\mathrm{Sd} / \mathrm{Sl}$ and $\mathrm{Vd} / \mathrm{Vl}$ ratios as it is not affected by the leaching/adsorption processes between carbon pools. Therefore, the Terr-OC in the ESAS is more degraded in the POC and SOC pools.

Two cinnamyl phenols, $p$-coumaric acid $(p \mathrm{Cd}$ ) and ferulic acid $(\mathrm{Fd})$, are additional $\mathrm{CuO}$ oxidation products of lignin that are particularly abundant in grasses and many herbaceous tissues. The two phenols differ by a presence of a methoxyl group, and this may explain the preferential degradation of ferulic acid (Opsahl and Benner, 1998). Therefore, $p \mathrm{Cd} / \mathrm{Fd}$ ratio has been used as a diagenetic indicator (Amon et al., 2012; Houel et al., 2006). In this data set $p \mathrm{Cd} / \mathrm{Fd}$ ratios follow the same pattern as the ones observed in 3,5$\mathrm{Bd} / \mathrm{V}$ ratios with higher values in POC and SOC and a slightly increasing tendency in the eastern SOC samples (Tables 1, 2 and 3; Fig. 9c). This strengthens the hypothesis that POC and SOC are more degraded than DOC.

The strong relationship between lignin concentrations and the ${ }^{14} \mathrm{C}$-age of DOC SPE also reflects the role of diagenetic processes. The younger the marine DOC is, the higher is the concentration of lignin (Fig. 7). Those relationships are consistent with previous observations in the Arctic Ocean where the age of DOC decreased with increasing concentration of lignin (Benner et al., 2004). These results suggest that a large proportion of DOC exported to the outer shelf of the ESAS, off the Lena River, comes from recently produced vascular plant material with little exposure to microbial degradation. Whereas most of terrigenous POC settles out close to land and is transported through repeated cycles of deposition and resuspension across the shelf, DOC is dispersed further out onto the EAS with variable extents of conservative mixing.

\section{Conclusions}

This extensive study provides improved understanding on the sources and composition of Terr-OC in the DOC, POC and SOC pools in the extensive outer ESAS. The distribution of a wide variety of bulk $\left(\delta^{13} \mathrm{C}\right.$ and $\left.\Delta^{14} \mathrm{C}\right)$ and macromolecular proxies (lignin-derived phenols) reflects a strong influence of the Lena River on the outer shelf, both in the Laptev Sea and the western ESS. These findings demonstrate that a large proportion of the surface DOC exported off-shelf comes from "young" and fresh vascular plant material. The older and more enriched $\delta^{13} \mathrm{C}$ signatures in the E-ESS and its higher POC and SOC concentrations suggest a greater influence of sea-ice coverage and the Pacific inflow. Near-bottom waters present more depleted $\Delta^{14} \mathrm{C}$ signatures and higher concentrations of lignin, particularly within the POC pool. This is key evidence of decoupling of the POC and DOC pools and reflects the off-shelf transport of permafrost-derived $\mathrm{OC}$ in the nepheloid layer, through repeated cycles of deposition and resuspension across the shelf. The ratios of S / V indicate gymnosperm vegetation as the most important source of lignin, and increasing $\mathrm{S} / \mathrm{V}$ ratios in the easternmost samples reflect a relatively higher source contribution of tundra plants. Moreover, the opposite trends in the $\mathrm{Pn} / P$ and $P$ / V ratios also indicate that DOC primarily contain a terrigenous OC. Taking together S / V and C / V ratios we observe distinct clustering between DOC, POC and SOC, suggesting that those pools are carrying Terr-OC of partially different origin. Regarding the degradation state of Terr-OC, ligninphenols fingerprints are presenting contrasting results. While acid/aldehyde ratios are higher for DOC, possibly due to fractionation during leaching, 3,5-Bd / V and $p \mathrm{Cd} / \mathrm{Fd}$ ratios were enhanced in POC and SOC, suggesting more degradation. If this hypothesis is true, the remobilized OC from permafrost, which is mainly transported within POC and SOC pools, could experience less burial and more mineralization than the DOC pool. The high abundance of Terr-OC in the outer ESAS, particularly in the dissolved and sedimentary carbon pools, is a clear indicator of the magnitude of shelf to basin transport. Overall, the results are a key piece of evidence for decoupling of the DOC, POC and SOC pools in the ESAS and elucidate the off-shelf transport of permafrostderived OC in the particulate pool of near-bottom waters.

Acknowledgements. We thank the crew and personnel of the international SWERUS-C3 expedition 2014 onboard I/B Oden and the Swedish Polar Research Secretariat for logistics support. This study was supported by the Knut and Alice Wallenberg Foundation, Headquarters of the Russian Academy of Sciences (RAS), the Far Eastern Branch of the RAS, the Swedish Research Council (VR contract 621-2004-4039 and 621-2007-4631), the Russian Foundation of Basic Research (08-05-13572, 08-05-00191-a, and 07-05-00050a), the Nordic Council of Ministers Cryosphere Climate Carbon Initiative (project Defrost, contract 23001), the European Research Council (ERC-AdG project CC-TOP \#695331) 
and the US National Science Foundation (OPP ARC 0909546). The contribution of Tommaso Tesi is 1901 of ISMAR-CNR Sede di Bologna. Igor P. Semiletov thanks the Russian Government for support (megagrant \#2013-220-04-157 under contract 14.Z50.31.0012). Joan A. Salvadó acknowledges EU financial support as a Marie Curie grant (FP7-PEOPLE-2012-IEF; project 328049).

Edited by: F. Peterse

Reviewed by: two anonymous referees

\section{References}

Alling, V., Porcelli, D., Morth, C. M., Anderson, L. G., SanchezGarcia, L., Gustafsson, O., Andersson, P. S., and Humborg, C.: Degradation of terrestrial organic carbon, primary production and out-gassing of $\mathrm{CO}_{2}$ in the Laptev and East Siberian Seas as inferred from delta C-13 values of DIC, Geochim. Cosmochim. Ac., 95, 143-159, 2012.

Alling, V., Sanchez-Garcia, L., Porcelli, D., Pugach, S., Vonk, J. E., van Dongen, B., Morth, C.-M., Anderson, L. G., Sokolov, A., Andersson, P., Humborg, C., Semiletov, I., and Gustafsson, O.: Nonconservative behavior of dissolved organic carbon across the Laptev and East Siberian seas, Global Biogeochem. Cy., 24, 143159,2010

Amon, R. M. W. and Benner, R.: Combined neutral sugars as indicators of the diagenetic state of dissolved organic matter in the Arctic Ocean, Deep-Sea Res. Pt. I, 50, 151-169, 2003.

Amon, R. M. W. and Meon, B.: The biogeochemistry of dissolved organic matter and nutrients in two large Arctic estuaries and potential implications for our understanding of the Arctic Ocean system, Mar. Chem., 92, 311-330, 2004.

Amon, R. M. W., Rinehart, A. J., Duan, S., Louchouarn, P., Prokushkin, A., Guggenberger, G., Bauch, D., Stedmon, C., Raymond, P. A., Holmes, R. M., McClelland, J. W., Peterson, B. J., Walker, S. A., and Zhulidov, A. V.: Dissolved organic matter sources in large Arctic rivers, Geochim. Cosmochim. Ac., 94, 217-237, 2012.

Arndt, D. S., Blunden, J., and Willett, K. W.: State of the climate in 2014, B. Am. Meteorol. Soc., 96, doi:10.1175/2014BAMSStateoftheClimate.1, 2015.

Baldock, J. A., Oades, J. M., Waters, A. G., Peng, X., Vassallo, A. M., and Wilson, M. A.: Aspects of the chemical structure of soil organic materials as revealed by solid-state13C NMR spectroscopy, Biogeochemistry, 16, 1-42, 1992.

Benner, R., Benitez-Nelson, B., Kaiser, K., and Amon, R. M. W.: Export of young terrigenous dissolved organic carbon from rivers to the Arctic Ocean, Geophys. Res. Lett., 31, doi:10.1029/2003g1019251, 2004.

Benner, R. and Kaiser, K.: Biological and photochemical transformations of amino acids and lignin phenols in riverine dissolved organic matter, Biogeochemistry, 102, 209-222, 2011.

Benner, R., Louchouarn, P., and Amon, R. M. W.: Terrigenous dissolved organic matter in the Arctic Ocean and its transport to surface and deep waters of the North Atlantic, Global Biogeochem. Cy., 19, doi:10.1029/2004gb002398, 2005.

Benner, R., Weliky, K., and Hedges, J. I.: Early diagenesis of mangrove leaves in a tropical estuary: Molecular-level analy- ses of neutral sugars and lignin-derived phenols, Geochim. Cosmochim. Ac., 54, 1991-2001, 1990.

Bröder, L., Tesi, T., Salvadó, J. A., Semiletov, I. P., Dudarev, O. V., and Gustafsson, Ö.: Fate of terrigenous organic matter across the Laptev Sea from the mouth of the Lena River to the deep sea of the Arctic interior, Biogeosciences, 13, 5003-5019, doi:10.5194/bg-13-5003-2016, 2016.

Charkin, A. N., Dudarev, O. V., Semiletov, I. P., Kruhmalev, A. V., Vonk, J. E., Sánchez-García, L., Karlsson, E., and Gustafsson, Ö.: Seasonal and interannual variability of sedimentation and organic matter distribution in the Buor-Khaya Gulf: the primary recipient of input from Lena River and coastal erosion in the southeast Laptev Sea, Biogeosciences, 8, 2581-2594, doi:10.5194/bg8-2581-2011, 2011.

Cooper, L. W., McClelland, J. W., Holmes, R. M., Raymond, P. A., Gibson, J. J., Guay, C. K., and Peterson, B. J.: Flowweighted values of runoff tracers $\left(\delta^{18} \mathrm{O}, \mathrm{DOC}, \mathrm{Ba}\right.$, alkalinity) from the six largest Arctic rivers, Geophys. Res. Lett., 35, doi:10.1029/2008g1035007, 2008.

Dickens, A. F., Gudeman, J. A., Gelinas, Y., Baldock, J. A., Tinner, W., Hu, F. S., and Hedges, J. I.: Sources and distribution of CuOderived benzene carboxylic acids in soils and sediments, Org. Geochem., 38, 1256-1276, 2007.

Dittmar, T. and Kattner, G.: The biogeochemistry of the river and shelf ecosystem of the Arctic Ocean: a review, Mar. Chem., 83, 103-120, 2003a.

Dittmar, T. and Kattner, G.: Recalcitrant dissolved organic matter in the ocean: major contribution of small amphiphilics, Mar. Chem., 82, 115-123, 2003b.

Druffel, E. R. M. and Bauer, J. E.: Radiocarbon distributions in Southern Ocean dissolved and particulate organic matter, Geophys. Res. Lett., 27, 1495-1498, 2000.

Eglinton, T. I. and Repeta, D. J.: Organic matter in the contemporary ocean, in: Tratise on Geochemistry, edited by: Elderfield, H. Woods Hole Oceanographic Institution, 2006.

Elmquist, M., Semiletov, I., Guo, L., and Gustafsson, O.: PanArctic patterns in black carbon sources and fluvial discharges deduced from radiocarbon and PAH source apportionment markers in estuarine surface sediments, Global Biogeochem. Cy., 22 doi:10.1029/2007gb002994, 2008.

Farella, N., Lucotte, M., Louchouarn, P., and Roulet, M.: Deforestation modifying terrestrial organic transport in the Rio Tapajos, Brazilian Amazon, Org. Geochem., 32, 1443-1458, 2001.

Feng, X., Vonk, J. E., van Dongen, B. E., Gustafsson, O., Semiletov, I. P., Dudarev, O. V., Wang, Z., Montlucon, D. B., Wacker, L., and Eglinton, T. I.: Differential mobilization of terrestrial carbon pools in Eurasian Arctic river basins, P. Natl. Acad. Sci. USA, 110, 14168-14173, 2013.

Fichot, C. G. and Benner, R.: The fate of terrigenous dissolved organic carbon in a river-influenced ocean margin, Global Biogeochem. Cy., 28, 300-318, 2014.

Follett, C. L., Repeta, D. J., Rothman, D. H., Xu, L., and Santinelli, C.: Hidden cycle of dissolved organic carbon in the deep ocean, P. Natl. Acad. Sci. USA, 111, 16706-16711, 2014.

Goni, M. A. and Hedges, J. I.: Lignin dimers: Structures, distribution, and potential geochemical applications, Geochim. Cosmochim. Ac., 56, 4025-4043, 1992.

Goni, M. A. and Hedges, J. I.: Sources and reactivities of marinederived organic matter in coastal sediments as determined by 
alkaline $\mathrm{CuO}$ oxidation, Geochim. Cosmochim. Ac., 59, 29652981, 1995.

Goni, M. A. and Montgomery, S.: Alkaline $\mathrm{CuO}$ oxidation with a microwave digestion system: Lignin analyses of geochemical samples, Anal. Chem., 72, 3116-3121, 2000.

Goni, M. A., Yunker, M. B., Macdonald, R. W., and Eglinton, T. I.: Distribution and sources of organic biomarkers in arctic sediments from the Mackenzie River and Beaufort Shelf, Mar. Chem., 71, 23-51, 2000.

Goni, M. A., Yunker, M. B., Macdonald, R. W., and Eglinton, T. I.: The supply and preservation of ancient and modem components of organic carbon in the Canadian Beaufort Shelf of the Arctic Ocean, Mar. Chem., 93, 53-73, 2005.

Gorham, E.: Northern peatlands - role in the carbon-cycle and probable responses to climatic warming, Ecol. Appl., 1, 182-195, 1991.

Griffith, D. R., McNichol, A. P., Xu, L., McLaughlin, F. A., Macdonald, R. W., Brown, K. A., and Eglinton, T. I.: Carbon dynamics in the western Arctic Ocean: insights from full-depth carbon isotope profiles of DIC, DOC, and POC, Biogeosciences, 9, 1217-1224, doi:10.5194/bg-9-1217-2012, 2012.

Guo, L., Ping, C.-L., and Macdonald, R. W.: Mobilization pathways of organic carbon from permafrost to arctic rivers in a changing climate, Geophys. Res. Lett., 34, doi:10.1029/2007g1030689, 2007.

Hedges, J. I., Clark, W. A., Quay, P. D., Richey, J. E., Devol, A. H., and Santos, U. D.: Compositions and fluxes of particulate organic material in the Amazon river, Limnol. Oceanogr., 31, 717-738, 1986.

Hedges, J. I. and Mann, D. C.: Lignin geochemistry of marinesediments from the southern Washington coast, Geochim. Cosmochim. Ac., 43, 1809-1818, 1979.

Hedges, J. I. and Oades, J. M.: Comparative organic geochemistries of soils and marine sediments, Org. Geochem., 27, 319-361, 1997.

Hedges, J. I. and Prahl, F. G.: Early diagenesis: consequences for applications of molecular biomarkers, in: Organic Geochemistry, Principles and Applications, edited by: Engel, M. H., Macko, S. A., and Jones, D. S., Plenum Press, New York, 1993.

Hernes, P. J. and Benner, R.: Photochemical and microbial degradation of dissolved lignin phenols: Implications for the fate of terrigenous dissolved organic matter in marine environments, J. Geophys. Res.-Oceans, 108, doi:10.1029/2002jc001421, 2003.

Hernes, P. J. and Benner, R.: Transport and diagenesis of dissolved and particulate terrigenous organic matter in the North Pacific Ocean, Deep-Sea Res. Pt. I, 49, 2119-2132, 2002.

Hernes, P. J., Robinson, A. C., and Aufdenkampe, A. K.: Fractionation of lignin during leaching and sorption and implications for organic matter "freshness", Geophys. Res. Lett., 34, doi:10.1029/2007g1031017, 2007.

Houel, S., Louchouarn, P., Lucotte, M., Canuel, R., and Ghaleb, B.: Translocation of soil organic matter following reservoir impoundment in boreal systems: Implications for in situ productivity, Limnol. Oceanogr., 51, 1497-1513, 2006.

Hugelius, G. and Kuhry, P.: Landscape partitioning and environmental gradient analyses of soil organic carbon in a permafrost environment, Global Biogeochem. Cy., 23, doi:10.1029/2008gb003419, 2009.
Karlsson, E., Gelting, J., Tesi, T., van Dongen, B., Semiletov, I. P., Charkin, A., Dudarev, O. V., and Gustafsson, Ö.: Different sources and degradation state of dissolved, particulate and sedimentary organic matter along the Eurasian Arctic coastal margin, Global Biogeochem. Cy., 30, 898-919, 2016.

Karlsson, E. S., Bruchert, V., Tesi, T., Charkin, A., Dudarev, O., Semiletov, I., and Gustafsson, O.: Contrasting regimes for organic matter degradation in the East Siberian Sea and the Laptev Sea assessed through microbial incubations and molecular markers, Mar. Chem., 170, 11-22, 2015.

Karlsson, E. S., Charkin, A., Dudarev, O., Semiletov, I., Vonk, J. E., Sánchez-García, L., Andersson, A., and Gustafsson, Ö.: Carbon isotopes and lipid biomarker investigation of sources, transport and degradation of terrestrial organic matter in the Buor-Khaya Bay, SE Laptev Sea, Biogeosciences, 8, 1865-1879, doi:10.5194/bg-8-1865-2011, 2011.

Kattner, G., Lobbes, J. M., Fitznar, H. P., Engbrodt, R., Nothig, E. M., and Lara, R. J.: Tracing dissolved organic substances and nutrients from the Lena River through Laptev Sea (Arctic), Mar. Chem., 65, 25-39, 1999.

Köhler, H., Meon, B., Gordeev, V. V., Spitzy, A., and Amon, R. M. W.: Dissolver organic matter (DOM) in the estuaries of $\mathrm{Ob}$ and Yenisei and the adjacent Kara Sea, Russia, in: Siberian River Run-off in the Kara Sea, edited by: Stein, R., Fahl, K., Fütterer, D. K., Galimov, E. M., and Stepanets, O. V., Elsevier Science, Amsterdam, 2003.

Lantuit, H., Overduin, P. P., and Wetterich, S.: Recent Progress Regarding Permafrost Coasts, Permafrost Periglacial Process., 24, 120-130, 2013.

Lobbes, J. M., Fitznar, H. P., and Kattner, G.: Biogeochemical characteristics of dissolved and particulate organic matter in Russian rivers entering the Arctic Ocean, Geochim. Cosmochim. Ac., 64, 2973-2983, 2000.

Louchouarn, P., Lucotte, M., and Farella, N.: Historical and geographical variations of sources and transport of terrigenous organic matter within a large-scale coastal environment, Org. Geochem., 30, 675-699, 1999.

Louchouarn, P., Opsahl, S., and Benner, R.: Isolation and quantification of dissolved lignin from natural waters using solid-phase extraction and GC/MS, Anal. Chem., 72, 2780-2787, 2000.

McClelland, J. W., Holmes, R. M., Peterson, B. J., Raymond, P. A., Striegl, R. G., Zhulidov, A. V., Zimov, S. A., Zimov, N., Tank, S. E., Spencer, R. G. M., Staples, R., Gurtovaya, T. Y., and Griffin, C. G.: Particulate organic carbon and nitrogen export from major Arctic rivers, Global Biogeochem. Cy., 30, doi:10.1002/2015GB005351, 2016.

McGuire, A. D., Anderson, L. G., Christensen, T. R., Dallimore, S., Guo, L., Hayes, D. J., Heimann, M., Lorenson, T. D., Macdonald, R. W., and Roulet, N.: Sensitivity of the carbon cycle in the Arctic to climate change, Ecol. Monogr., 79, 523-555, 2009.

McGuire, A. D., Macdonald, R. W., Schuur, E. A. G., Harden, J. W., Kuhry, P., Hayes, D. J., Christensen, T. R., and Heimann, M.: The carbon budget of the northern cryosphere region, Current Opinion in Environmental Sustainability, 2, 231-236, 2010.

Opsahl, S. and Benner, R.: Early diagenesis of vascular plant-tissues - lignin and cutin decomposition and biogeochemical implications, Geochim. Cosmochim. Ac., 59, 4889-4904, 1995. 
Opsahl, S. and Benner, R.: Photochemical reactivity of dissolved lignin in river and ocean waters, Limnol. Oceanogr., 43, 12971304, 1998.

Opsahl, S., Benner, R., and Amon, R. M. W.: Major flux of terrigenous dissolved organic matter through the Arctic Ocean, Limnol. Oceanogr., 44, 2017-2023, 1999.

Otto, A. and Simpson, M. J.: Evaluation of $\mathrm{CuO}$ oxidation parameters for determining the source and stage of lignin degradation in soil, Biogeochemistry, 80, 121-142, 2006.

Pasqual, C., Goni, M. A., Tesi, T., Sanchez-Vidal, A., Calafat, A., and Canals, M.: Composition and provenance of terrigenous organic matter transported along submarine canyons in the Gulf of Lion (NW Mediterranean Sea), Prog. Oceanogr., 118, 81-94, 2013.

Peterson, B. J., Holmes, R. M., McClelland, J. W., Vorosmarty, C. J., Lammers, R. B., Shiklomanov, A. I., Shiklomanov, I. A., and Rahmstorf, S.: Increasing river discharge to the Arctic Ocean, Science, 298, 2171-2173, 2002.

Prahl, F. G., Ertel, J. R., Goni, M. A., Sparrow, M. A., and Eversmeyer, B.: Terrestrial organic carbon contributions to sediments on the Washington margin, Geochim. Cosmochim. Ac., 58, 3035-3048, 1994.

Raymond, P. A., McClelland, J. W., Holmes, R. M., Zhulidov, A. V., Mull, K., Peterson, B. J., Striegl, R. G., Aiken, G. R., and Gurtovaya, T. Y.: Flux and age of dissolved organic carbon exported to the Arctic Ocean: A carbon isotopic study of the five largest arctic rivers, Global Biogeochem. Cy., 21, doi:10.1029/2007gb002934, 2007.

Salvadó, J. A., Tesi, T., Andersson, A., Ingri, J., Dudarev, O. V., Semiletov, I. P., and Gustafsson, Ö.: Organic carbon remobilized from thawing permafrost is resequestered by reactive iron on the Eurasian Arctic Shelf, Geophys. Res. Lett., 42, 8122-8130, 2015.

Sanchez-Garcia, L., Alling, V., Pugach, S., Vonk, J. E., van Dongen, B., Humborg, C., Dudarev, O., Semiletov, I., and Gustafsson, O.: Inventories and behavior of particulate organic carbon in the Laptev and East Siberian seas, Global Biogeochem. Cy., 25, doi:10.1029/2010gb003862, 2011.

Sanchez-Garcia, L., Vonk, J. E., Charkin, A. N., Kosmach, D., Dudarev, O. V., Semiletov, I. P., and Gustafsson, O.: Characterisation of Three Regimes of Collapsing Arctic Ice Complex Deposits on the SE Laptev Sea Coast using Biomarkers and Dual Carbon Isotopes, Permafrost Periglacial Process., 25, 172-183, 2014.

Schreiner, K. M., Bianchi, T. S., Eglinton, T. I., Allison, M. A., and Hanna, A. J. M.: Sources of terrigenous inputs to surface sediments of the Colville River Delta and Simpson's Lagoon, Beaufort Sea, Alaska, J. Geophys. Res.-Biogeo., 118, 808-824, 2013.

Schubert, C. J. and Calvert, S. E.: Nitrogen and carbon isotopic composition of marine and terrestrial organic matter in Arctic Ocean sediments: implications for nutrient utilization and organic matter composition, Deep-Sea Res. Pt. I, 48, 789-810, 2001

Selver, A. D., Sparkes, R. B., Bischoff, J., Talbot, H. M., Gustafsson, O., Semiletov, I. P., Dudarev, O. V., Boult, S., and van Dongen, B. E.: Distributions of bacterial and archaeal membrane lipids in surface sediments reflect differences in input and loss of terrestrial organic carbon along a cross-shelf Arctic transect, Org. Geochem., 83-84, 16-26, 2015.
Semiletov, I., Pipko, I., Gustafsson, O., Anderson, L. G., Sergienko, V., Pugach, S., Dudarev, O., Charkin, A., Gukov, A., Broder, L., Andersson, A., Spivak, E., and Shakhova, N.: Acidification of East Siberian Arctic Shelf waters through addition of freshwater and terrestrial carbon, Nat. Geosci., 9, 361-365, 2016.

Semiletov, I. P., Dudarev, O., Luchin, V., Charkin, A., Shin, K. H., and Tanaka, N.: The East Siberian sea as a transition zone between Pacific-derived waters and Arctic shelf waters, Geophys. Res. Lett., 32, doi:10.1029/2005GL022490, 2005.

Semiletov, I. P., Pipko, I. I., Shakhova, N. E., Dudarev, O. V., Pugach, S. P., Charkin, A. N., McRoy, C. P., Kosmach, D., and Gustafsson, Ö.: Carbon transport by the Lena River from its headwaters to the Arctic Ocean, with emphasis on fluvial input of terrestrial particulate organic carbon vs. carbon transport by coastal erosion, Biogeosciences, 8, 2407-2426, doi:10.5194/bg8-2407-2011, 2011

Semiletov, I. P., Savelieva, N. I., Weller, G. E., Pipko, II, Pugach, S. P., Gukov, A. Y., and Vasilevskaya, L. N.: The dispersion of Siberian river flows into coastal waters: Meteorological, hydrological and hydrochemical aspects, Springer, Dordrecht, 2000.

Serreze, M. C., Bromwich, D. H., Clark, M. P., Etringer, A. J., Zhang, T. J., and Lammers, R.: Large-scale hydro-climatology of the terrestrial Arctic drainage system, J. Geophys. Res.-Atmos., 108, doi:10.1029/2001jd000919, 2002.

Spencer, R. G. M., Aiken, G. R., Wickland, K. P., Striegl, R. G., and Hernes, P. J.: Seasonal and spatial variability in dissolved organic matter quantity and composition from the Yukon River basin, Alaska, Global Biogeochem. Cy., 22, doi:10.1029/2008gb003327, 2008.

Stein, R. and Macdonald, R. W.: The organic carbon cycle in the Arctic Ocean, Springer, 2004.

Tarnocai, C., Canadell, J. G., Schuur, E. A. G., Kuhry, P., Mazhitova, G., and Zimov, S.: Soil organic carbon pools in the northern circumpolar permafrost region, Global Biogeochem. Cy., 23, 11 doi:10.1029/2007gb002974, 2009.

Tesi, T., Semiletov, I., Dudarev, O., Andersson, A., and Gustafsson, O.: Matrix association effects on hydrodynamic sorting and degradation of terrestrial organic matter during cross-shelf transport in the Laptev and East Siberian shelf seas, J. Geophys. Res.Biogeo., 121, 731-752, 2016.

Tesi, T., Semiletov, I., Hugelius, G., Dudarev, O., Kuhry, P., and Gustafsson, O.: Composition and fate of terrigenous organic matter along the Arctic land-ocean continuum in East Siberia: Insights from biomarkers and carbon isotopes, Geochim. Cosmochim. Ac., 133, 235-256, 2014.

van Dongen, B. E., Semiletov, I., Weijers, J. W. H., and Gustafsson, O.: Contrasting lipid biomarker composition of terrestrial organic matter exported from across the Eurasian Arctic by the five great Russian Arctic rivers, Global Biogeochem. Cy., 22, doi:10.5194/bg-7-3153-2010, 2008a.

van Dongen, B. E., Zencak, Z., and Gustafsson, O.: Differential transport and degradation of bulk organic carbon and specific terrestrial biomarkers in the surface waters of a sub-arctic brackish bay mixing zone, Mar. Chem., 112, 203-214, 2008b.

Vonk, J. E. and Gustafsson, O.: Permafrost-carbon complexities, Nat. Geosci., 6, 675-676, 2013.

Vonk, J. E., Sanchez-Garcia, L., van Dongen, B. E., Alling, V., Kosmach, D., Charkin, A., Semiletov, I. P., Dudarev, O. V., Shakhova, N., Roos, P., Eglinton, T. I., Andersson, A., and 
Gustafsson, O.: Activation of old carbon by erosion of coastal and subsea permafrost in Arctic Siberia, Nature, 489, 137-140, 2012.

Vonk, J. E., van Dongen, B. E., and Gustafsson, O.: Selective preservation of old organic carbon fluvially released from subArctic soils, Geophys. Res. Lett., 37, doi:10.5194/bg-7-31532010, 2010

Ward, N. D., Keil, R. G., Medeiros, P. M., Brito, D. C., Cunha, A. C., Dittmar, T., Yager, P. L., Krusche, A. V., and Richey, J. E.: Degradation of terrestrially derived macromolecules in the Amazon River, Nat. Geosci., 6, 530-533, 2013.
Williams, C. J., Yavitt, J. B., Wieder, R. K., and Cleavitt, N. L.: Cupric oxide oxidation products of northern peat and peatforming plants, Canadian Journal of Botany-Revue Canadienne De Botanique, 76, 51-62, 1998.

Winterfeld, M., Goñi, M. A., Just, J., Hefter, J., and Mollenhauer, G.: Characterization of particulate organic matter in the Lena River delta and adjacent nearshore zone, NE Siberia - Part 2: Lignin-derived phenol compositions, Biogeosciences, 12, 22612283, doi:10.5194/bg-12-2261-2015, 2015.

Zwiers, F. W.: Climate change - The 20-year forecast, Nature, 416, 690-691, 2002. 